\title{
Sosyal Bilgiler Öğretmenlerinin ve Öğretmen Adaylarının Evrensel Değerlere ilişskin Metafor Algıları ${ }^{1}$
}

\author{
Doç. Dr. Tekin Çelikkaya \\ Ahi Evran Üniversitesi-Türkiye \\ tcelikkaya@gmail.com
}

\author{
Osman Seyhan (Y.l.Öğr.) \\ Ahi Evran Üniversitesi-Türkiye \\ osmanseyhan40@gmail.com
}

\begin{abstract}
Özet:
Sosyal bilgiler öğretmenlerinin ve ögretmen adaylarının evrensel değerlere yönelik algılarını açıklamada kullandıkları metaforları tespit etmeyi amaçlayan bu çalışma, tarama modelinde nitel bir araştırmadır. Veri toplama ve yorumlama sürecinde nitel araştırma yöntemleri desenlerinden biri olan olgu bilim (fenomenoloji) deseni kullanılmıştır. Araştırmada çalışma grubunu 2016-2017 öğretim yulında Ahi Evran Üniversitesi'nde ögrrenim görmekte olan 46'sı $(\% 43,40)$ kadın ve 60'ı $(\% 56,60)$ erkek olmak üzere 106 sosyal bilgiler öğretmen adayı ile Kırşehir il merkezinde görev yapan 40 sosyal bilgiler öğretmeni oluşturmaktadır. Veriler, araştırmacılar tarafından geliştirilen "Evrensel Değerlere Yönelik Sosyal Bilgiler Öğretmen ve Öğretmen Adayları Metaforları Yapılandırılmış Formu" aracılığıyla toplanmıştır. Araştırmada elde edilen metaforlarla öğretmen adayları metaforları için 32, öğretmenlerin metaforları için ise 27 farklı kategori geliştirilmiştir. Öğretmenler tarafından üretilen metaforlar, aydınlatmaya, temsiliyete yönelik, olmazsa olmaza, hareket alanını kısıtlamaya ve gittikçe artmaya büyümeye yönelik kategorilerinde yer bulmamıştır. Öğretmen adaylarının 9 değer için oluşturduğu toplam 233 metaforun 172'si birbirinden farklı olup 61 tanesi ise ortak olarak üretilen metaforlardır. En fazla özgürlük değeri (24) için en az ise barış ve saygı değerleri (14) için farklı metaforlar üretilmiştir. Öğretmenlerin 9 değer için oluşturduğu toplam 68 metaforun 51'i birbirinden farklı olup 17 tanesi ise ortak olarak üretilen metaforlardır. En fazla dürüstlük ve sevgi değerleri (8) için en az ise sorumluluk değeri (2) için farklı metafor üretilmiştir. Her iki grupta da en çok dürüstlük değeri için metafor üretilmiştir.
\end{abstract}

Anahtar Kelimeler: Evrensel değerler, metafor, sosyal bilgiler öğretmeni, sosyal bilgiler ögretmen adayı

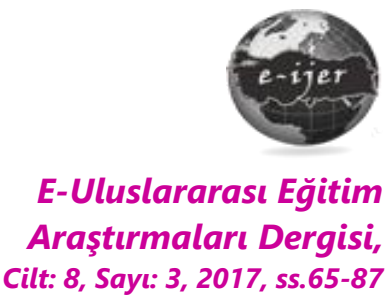

DOI: $10.19160 /$ ijer.342330

Gönderim : 08.10.2017 Kabul: 20.11 .2017

\section{Önerilen Atıf}

Çelikkaya, T. ve Seyhan, O. (2017). Sosyal Bilgiler Öğretmenlerinin ve Öğretmen Adaylarının Evrensel Değerlere İlişkin Metafor Algıları, E-Uluslararası Eğitim Araştırmaları Dergisi, Cilt: 8, Sayı: 3, 2017, ss. 65-87, DOI: 10.19160/ijer.342330

\footnotetext{
${ }^{1}$ Bu çalışma 8-10 Ağustos 2017 tarihleri arasinda The $3^{\text {nd }}$ International Conference on the Changing World and Social Research (ICWSR'2017), Rome -ITALY, sempozyumunda sunulan sözlü bildirinin genişletilmiş halidir
} 


\section{GiRiş}

Sosyal Bilgiler, sosyal bilimlerin bulgularını entegre edip öğrencilerin düzeyine göre basitleştiren, bunları kullanarak, bireylere sosyal yaşama uyum sağlamada ve sosyal sorunlara çözüm üretmede intiyaç duyacakları bilgi, beceri, tutum ve değerleri kazandırmayı amaçlayan bir yurttaşıık eğitimi programı olarak nitelendirilmektedir (Öztürk ve Otluoğlu, 2011: 6).

Değerler hem mikro hem de makro anlama sahip kavramlardır. Mikro seviyesinde bireysel davranışın değerleri, bireyin ihtiyaçları ile toplumsal yaşamın taleplerini uzlaştıran içselleştirilmiş standartlardır. Bu durumda değerler bireylere eylemleri için uygun seçenekleri sunmaktadır. Makro düzlemde ise kültürel yaşam gibi değerler toplumsal yaşamla bütünleşmeye olanak veren paylaşılan anlamları anlatmaktadır (Parashar, Dhar \& Dhar, 2004:144).

Değerler, insanların iyiyi, doğruyu, güzeli ve çirkini tanımlamak için koymuş oldukları standartlar olup hangi toplumsal davranışların iyi, doğru ve istendik olduğunu belirten, paylaşılan ölçüt ve fikirlerdir (Özkalp, 2003:64). Değerler, insanların değer verdiği ve ulaşmak için peşinden koştuğu, elde etmeyi arzu ettiği şeylerdir. Bunlar mal, mülk, servet, sıhhat gibi değerler olduğu gibi, mutluluk, huzur, Allah sevgisi, vatan sevgisi ve özgürlük gibi tamamen manevî değerler de olabilir (Bolay, 2010:14). Değerlerin sadece kişiye özgü bir olguyu anlatmıyor olması ve bireyler arasında paylaşılıyor olması özelliği bizim ulusal değerler, aile değerleri, evrensel değerler, gençlik değerleri ve örgütsel değerler gibi tanımlamalar yapmamıza olanak sağlamaktadır (Balcı ve Yelken Yanpar, 2010:81). Bununla birlikte değerler konusunda birçok sınıflama bulunmaktadır. Spranger (1928) yaptığı çalışmalar sonucunda değerleri estetik, bilimsel, ekonomik, siyasi, sosyal ve dini değerler olarak altı grupta, Rokeach (1973) amaç ve araç değerler olarak iki grupta (Akt. Akbaş, 2004), Schwartz (1964:5-11) ise değerleri özyönelim, uyarılım, hazcılık, başarı, güç, güvenlik, uyma, geleneksellik, iyilikseverlik ve evrenselcilik olmak üzere on farklı grupta incelemiştir.

Thomas Lickona değerleri, saygı ve sorumluluk başta olmak üzere hoşgörü, basiret, özdisiplin, yardımseverlik, merhamet, iş birliği, cesaret, dürüstlük, adil olma ve demokratik değerler olarak, Edward Wynne ve Kevin Ryan, adalet, basiret, ölçülülük, cesaret, inanç, umut, yardımseverlik, saygı olarak, William Bennet, merhamet, özdisiplin, sorumluluk, çalışma, arkadaşlık, cesaret, azim, dürüstlük, sadakat ve inanç olarak belirlemişlerdir (Leming, 1996; Akt: Avcı, 2009:156). Ercan (2001) ise değerleri ulusal ve evrensel değerler olarak ikiye ayırmıştır. Ulusal Değerler: Millet, devlet, vatan, ordu, cumhuriyet, kahramanlık, dil, gelenek görenekler ile ulusal marş bayrak ve ulusal bayramların oluşturduğu ulusal simgelerdir. Evrensel Değerler: Demokrasi, insan hakları ve özgürlükleri, bağımsızlık, uygarlık, barış, hoşgörü, saygı, sevgi, anlayış uzlaşma, bilim, eşitlik, çevre duyarlılı̆ı olarak kabul edilmiştir.

Insanların ahlaki özünde oluşan değerlerin bazıları evrenseldir. Yani bu değerler bir toplum için değil tüm toplumlar için önemlidir. Adalet, eşitlik, özgürlük, insana saygı, dürüstlük, çalışkanlık vb. tüm insanlar için aynı değere ve öneme sahiptir. Bu nedenle evrensel değerlerin insanlar tarafından korunması ve yaşama geçirilmesi yönünde sorumlulukları vardır (Doğan, 2007: 231). Sevgi, savaş, ölüm evrenseldir diyebiliriz ya da bu kelimelerin oluşturduğu ortamlar hakkında insanlara ışık tutacak açıklamalar yapabiliriz. Bu şekilde evrensellikten ne anladığımız da ortaya çıkacaktır. Bir rastlantısal dünyanın uçan kelimelerinden biri olan "evrensellik" yine o başıboşluk çerçevesinde hayat bulur ve o hızda yok olur gider; bizlerin bahsettiği de sadece onun hatırası olur (Koç, 2007:51).

Sosyal Bilgiler dersi bir değer eğitimi dersidir. 2005 ve 2017 yıllarında gerçekleştirilen program değişikliklerinde dikkati çeken hususlardan biri de değer eğitimi konusunun, programlar içinde vurgulanmasıdır. 2005 Sosyal Bilgiler Öğretim Programı incelendiğinde öğrencilere toplam 20 değerin kazandırılması hedeflenmektedir. Bu değerler; "Adil olma, Aile birliğine önem verme, Barış, Bağımsızlık, Bilimsellik, Çalışkanlık, Dayanışma, Duyarlıık, Dürüstlük, Estetik, Hoşgörü, Misafirperverlik, Özgürlük, Saygı, Sağlıkı olmaya önem verme, Sevgi, Sorumluluk, 
Temizlik, Vatanseverlik, Yardımseverlik" (Evirgen, 2016; Karabıyık, 2016; Özensoy ve Aynacı, 2016; Şahin, Bayram ve Midilli, 2016) olarak belirlenmiștir. 2017 Sosyal Bilgiler Öğretim Programı incelendiğinde bu değerlerden bazıları çıkarılıp (hoşgörü, misafirperverlik, sağlıklı olmaya önem verme, temizlik) yeni eklemelerle (eşitlik ve tasarruf) 18 değerin kazandırılması hedeflenmektedir (Milli Eğitim Bakanlığı [MEB], 2017).

Bu araştırma kapsamında Barış, Bilimsellik, Dürüstlük, Özgürlük, Saygı, Sevgi, Sorumluluk, Vatanseverlik, Yardımseverlik değerleri incelenmiştir. Belirlenen bu değerler hem toplumsal, hem bireysel hem de aile değerleri kapsamındadır.Seçilen bu değerler diğer araştırmacılar tarafından yapılan sınıflandırmalara baktığımızda evrensel ve ulusal değerlerin (Balcı ve Yelken Yanpar, 2010; Doğan, 2007; Ercan, 2001; Schwartz, 1964; Spranger, 1928, Rokeach,1973 (Akt., Akbaş, 2004), Thomas Lickona (Akt: Avcı, 2009)) değer gruplamasında yer almakta olup ayrıca İlköğretim Hayat Bilgisi (1-3.sınıflar), Türkçe (1-8.sınıflar), Sosyal Bilgiler (47.sınıflar) ve Din Kültürü ve Ahlak Bilgisi (4-8.sınıflar) derslerinin 2005 ve 2017 öğretim programlarında öğrencilere kazandırılması hedeflenen ortak değerler olarakta geçmektedirler. Sosyal Bilgiler öğretmenlerinin ve öğretmen adaylarının hayat görüşünün, değer öğretiminde ve mesleğe yönelik tutumları üzerinde önemli etkilerinin olması beklenir. Bu düşünceden ve değerler eğitiminde sahip oldukları önemli rollerinden dolayı bu araştırmada öğretmenlerin ve öğretmen adaylarının evrensel değerleri nasıl kavramlaştırdıklarına odaklanılmıştır.Bu değerleri kavramsallaştırmanın yollarından biri de metaforlardır.

Aile gibi bir değere sahip olmadığınızda, geçmişten getirdiğiniz değerleri geleceğe taşımanız zorlaşır. Aile ortadan kalktığı zaman, dostluklar ortadan kalktığı zaman, insan saygısı ortadan kalktığı zaman gelenekten gelebilecek yüksek değerlerle bağınız kopar. Çünkü değerleri biz keşfetmedik. Hiçbir insan kendi başına değerleri keşfedemez. Daha doğrusu "keşif" sözü bir anlamıyla uygun değil, değerleri keşfedebiliriz ama icat edemeyiz. Onlar bizim uydurduğumuz şeyler olamaz. Bir bölümü, bu gezegendeki hayatın başlamasıyla birlikte insan dediğimiz canlı türünde ortaya çıkmış, varlıklarını hâlâ sürdürüyorlar. Bu açıdan, belki de Nicolai Hartmann çağdan çağa, toplumdan topluma değişmeyen "Evrensel değerler vardır." deyişiyle haklıdır (Ocakoğlu, 2009:86).

Bireyler, hem kendi duygu ve düşüncelerini tanımlarken, hem de karşılarındakilerin duygu ve düşüncelerini tanımlarken metaforlardan yararlanmaktadırlar. Bu da bireylerin yaşam algılarını ortaya koymada önemli bir öğe olarak görülmektedir. Bu bağlamda metaforlar, bireylerin dünyayı ve kendilerini algılama biçimlerini göstermektedir (Girmen, 2007: 12).

Metaforlar öğrenmeyi geliştirmek için son derece değerli araçlardır: eğer ki yeni bir şeyler keşfetmek istiyorsak, ilk olarak bunu hayal edebilmeliyiz. Ayrıca metaforlar, belirsiz bir kavramdan ziyade açık ve net fikirler inşa etmede bizim hayallerimizin anlamı olduğu için sezgisel bir değere sahiptir. Analojiler ve metaforlar, kavramsal sistemimizi ve öğrencilerin gördüğü dünyayı değiştirme gücüne sahiptir (Sanchez, Barreiro \& Maojo, 2000:358). Metafor, durumları ve olayları algılama yollarımızı etkilediği için gerçekleri yeniden tanımlamak ve problem durumlarını yeniden kavramsallaştırmayı teşvik etmek için de kullanılabilir (Goldstein, 2005:9). Ayrıca metafor, öğretmen eğitiminde teori ile uygulama arasındaki uçurumu birleştirmede de kullanılabilir (Leavy, McSorley \& Bote, 2007: 1219).

Metaforlar eğitimin çeşitli alanlarında kullanılabilmektedirler. Eğitim yönetiminde metaforlara müfredat geliştirme ve plânlamada; öğretim alanında da öğrenmeyi teşvik etme ve yaratıcı düşünceyi geliştirmede başvurulmaktadır. Öğretmen eğitiminde de metaforlar, öğretim uygulamalarını yönlendirmede ve öğretmenlerin modern eğitim anlayışındaki yerlerini belirlemede bir araç konumundadır (Vadeboncoeur \& Torres, 2003:88). Öğretmen, öğrencilere davranışlar konusunda doğru yolu gösteren "ahlaki bir pusula" olarak tanımlanmaktadır. Tüm değerler eğitimi yaklaşımları, örnek insan olarak öğretmenin önemini kabul etmekte; öğretmenlerin demokratik bir toplumda gereksinim duyulan değerler konusunda öğrencilere model olmasının önemine vurgu yapmaktadır (Chapin, 2006). 
Sosyal bilgiler öğretmenlerinin ve öğretmen adaylarının farklı konulara ilişkin görüşlerinin neler olduğunu anlamak için metaforlar birçok araştırmada (Meral, Küçük ve Gedik, 2016; Akhan, Kılıçoğlu ve Gedik, 2014; Demircioğlu, 2006; Çelikkaya ve Yakar, 2015; Tuna ve Budak, 2013; Kaya, 2014; Kaya, 2013; Koçoğlu, 2014; Özbaş, 2012) kullanıldığı gibi sadece bir ya da birkaç değere ilişkin çalışmalar (Mutluer, 2015) olmasına karşın programda olan değerleri kapsayıcı nitelikte hem sosyal bilgiler öğretmenlerinin hem de sosyal bilgiler öğretmen adaylarının değerlere ilişkin görüşlerinin neler olduğunu ortaya koyan metafor çalışmasına rastlanmamıştır.

\section{Araştırmanın Amacı}

Bu araştırmanın amacı, Sosyal Bilgiler öğretmenlerinin ve öğretmen adaylarının evrensel değerlere ilişkin geliştirdikleri metaforları incelemektir. Bu amaç doğrultusunda çalışmada evrensel değerlere yönelik;

1. Sosyal Bilgiler öğretmenlerinin ve öğretmen adaylarının evrensel değerlere ilişkin sahip oldukları metaforlar nelerdir?

2. Bu evrensel değerlere ilişkin ortaya çıkan metaforlar ortak özellikleri bakımından hangi kavramsal kategoriler altında toplanabilir?

\section{YÖNTEM}

Sosyal Bilgiler öğretmenlerinin ve öğretmen adaylarının evrensel değerlere yönelik algılarını açıklamada kullandıkları metaforları tespit etmeyi amaçlayan bu çalışma, tarama modelinde nitel bir araştırmadır. Veri toplama ve yorumlama sürecinde nitel araştırma yöntemleri desenlerinden biri olan olgu bilim deseni kullanılmıştır. Olgu bilim deseni, günlük yaşamda farkında olduğumuz ama derinlemesine ve ayrıntılı bir anlayışa sahip olmadığımız olgulara odaklanmaktadır. (Patton, 2014: 104; Yıldırım ve Şimşek, 2013: 78). Metaforlar çalışılan konuya ilişkin sağlam ve zengin bir resim sunma konusunda oldukça yararlıdır (Yıldırım ve Şimşek, 2013: 242). Schmitt (2005:360) de özellikle nitel araştırmalarda ulaşılan karmaşık bilgilerin açık ve anlaşıır örüntülere dönüştürülmesinde, metaforların çok kullanışlı olduğunu belirtmektedir.

\section{Çalışma Grubu:}

Çalışma grubu 2016-2017 eğitim-öğretim yılı Kırşehir ili merkez sınırları içerisinde yer alan 15 ortaokulda görev yapmakta olan 40 sosyal bilgiler öğretmeni ile yine aynı dönemde Ahi Evran Üniversitesi Eğitim Fakültesi Sosyal Bilgiler Eğitimi Anabilim Dalı'nda öğrenim gören 92 erkek,153 kadın olmak üzere toplamda 245 öğretmen adayından oluşmaktadır. Ancak yapılan analizlerde 83 erkek,134 kadın olmak üzere 217 öğretmen adayının kâğıdı geçerli olurken 9 erkek, 18 kadın olmak üzere toplam 27 öğretmen adayının kâğıdı geçersiz sayılarak kullanılmamıştır. 25 erkek,15 kadın olmak üzere toplamda 40 sosyal öğretmenine uygulama yapılmıştır (Tablo 1).

Araştırmaya katılan öğretmen ve öğretmen adaylarının belirlenmesinde amaçlı örneklem yöntemlerinden "ölçüt örnekleme" yaklaşımı tercih edilmiştir. Ölçüt örnekleme yöntemindeki temel anlayış, araştırmacı tarafından belirlenmiş ya da önceden hazırlanmış bir dizi ölçütü karşılayan bütün durumların çalışılmasıdır (Yıldırım ve şimşek, 2013:140). Bu çalışma için örnekleme dâhil edilebilecek katılımcılarda aranan ölçüt, evrensel değerler olarak adlandırılan 9 değerin sosyal bilgiler dersinde doğrudan öğretilecek değerler içerisinde yer alması, öğretmen adaylarına 3. ve 4.sınıflardaki alan eğitimi dersleri aracılığı ile aktarılmış olması ve sosyal bilgiler dersi aracılığı ile sosyal bilgiler öğretmenlerinin bu değerleri öğrencilere aktarmak zorunda olmalarıdır. Araştırmaya katılanların demografik özellikleri Tablo 1'de gösterilmiştir. 


\section{Tablo 1}

Katılımcıların Demografik Özellikleri

\begin{tabular}{|c|c|c|c|c|c|c|c|c|c|c|c|}
\hline & & \multicolumn{8}{|c|}{ Sosyal Bilgiler Öğretmen Adayları } & \multirow{2}{*}{\multicolumn{2}{|c|}{$\begin{array}{l}\text { Sosyal Bilgiler } \\
\text { Öğretmenleri }\end{array}$}} \\
\hline \multicolumn{2}{|l|}{ Sınıf } & \multicolumn{2}{|c|}{ 1.Sınıf } & \multicolumn{2}{|c|}{ 2.Sınıf } & \multicolumn{2}{|c|}{ 3.Sınıf } & \multicolumn{2}{|c|}{ 4.Sınıf } & & \\
\hline \multicolumn{2}{|l|}{ Cinsiyet } & 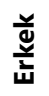 & $\begin{array}{l}\underline{\underline{g}} \\
\underline{\tilde{g}}\end{array}$ & 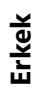 & $\begin{array}{l}\underline{\Xi} \\
\underline{\mathbb{\pi}}\end{array}$ & 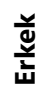 & 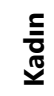 & 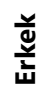 & $\begin{array}{l}\underline{\underline{g}} \\
\underline{\tilde{g}}\end{array}$ & 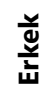 & $\begin{array}{l}\underline{\underline{\sigma}} \\
\underline{\tilde{J}}\end{array}$ \\
\hline Kullanılan & $\mathbf{n}$ & 18 & 30 & 18 & 32 & 18 & 44 & 29 & 28 & 25 & 15 \\
\hline $\begin{array}{l}\text { Kullanılan } \\
\text { Toplam }\end{array}$ & $\mathbf{n}$ & \multicolumn{2}{|c|}{48} & \multicolumn{2}{|c|}{50} & \multicolumn{2}{|c|}{62} & \multicolumn{2}{|c|}{57} & \multicolumn{2}{|c|}{40} \\
\hline Kullanılmayan & $\mathbf{n}$ & 3 & 7 & 5 & 9 & - & - & 1 & 2 & - & - \\
\hline $\begin{array}{c}\text { Kullanilmayan } \\
\text { Toplam }\end{array}$ & $\mathbf{n}$ & \multicolumn{2}{|c|}{10} & \multicolumn{2}{|c|}{14} & \multicolumn{2}{|c|}{ - } & \multicolumn{2}{|c|}{3} & & \\
\hline
\end{tabular}

\section{Veri Toplama Aracı}

Araştırmanın veri toplama aracı hazırlanırken, bireylerin sahip olduğu algıları ortaya çıkarmada metaforların bir araç olarak kullanıldığı ilgili araştırmalar incelenmiştir (Akhan, Kılıçoğlu ve Gedik, 2014; Çelikkaya ve Yakar, 2015; Demircioğlu, 2006; Kaya, 2014; Kaya, 2013; Koçoğlu, 2014;Meral, Küçük ve Gedik, 2016; Özbaş, 2012;Tuna ve Budak, 2013) Illgili araştırmalara dayanarak, verilerin toplanması sürecinde araştırmacılar tarafından geliştirilen "Evrensel değerlere yönelik yapılandırılmış form" kullanılmıştır. İlgili alan yazın taranması doğrultusunda geliştirilen ve iki bölümden oluşan yapılandırılmış formda toplam 11 soru bulunmaktadır. İki sorudan oluşan ilk bölüm kişisel bilgilere yönelik (öğretmenler için cinsiyet ve mesleki kıdem öğretmen adayları için cinsiyet ve sınıf düzeyi) iken dokuz maddeden oluşan ikinci bölüm ise öğretmenlerin ve öğretmen adaylarının evrensel değerlere yönelik algılarıyla ilgilidir. Etkinlik kâğıdının görünüş ve kapsam geçerliliği için iki alan uzmanından görüş alınarak etkinlik kâğıdına son hali verilmiştir. Uygulamadan önce araştırmacı tarafından katılımcılara farklı bir kavramla ilgili metafor geliştirme çalışması yaptırılmıştır. Öğretmenler ve öğretmen adayları tarafından doldurulan bu formlar birer belge ve doküman olarak bu araştırmanın temel veri kaynağını oluşturmaktadır.

\section{Verilerin Analizi ve Yorumlanması}

Çalışma grubunda yer alan katılımcıların "Evrensel değerlere" yönelik metaforlar ürettikleri dokümanların çözümlenmesi içerik analizi yöntemi ile yapılmış elde edilen bulgular tablolara dönüştürülerek yorumlanmıştır. Bu süreç beş aşamada gerçekleştirilmiştir:

\section{a. Adlandırma Aşaması:}

Bu aşamada basitçe her katılımcının kâğıtta ifade ettiği metafor kodlanmıştır (örneğin sarmaşık, ekmek, su, güneş vb.). Renkli kalemler kullanılarak, metaforun adı ayrıca katılımcı kâğıtlarında da işaretlendi. Herhangi bir metaforun tanımlanmadığı, katılımcıların herhangi bir şey yazmadığı veya oluşturulan metaforun mantıklı bir şekilde açıklanmadığı kâğıtlar "metafor yok" şeklinde (daha sonra elenmek üzere) işaretlenmiştir.

\section{b. Tasnif Aşaması:}

Bu aşamada, metafor analizi (Moser, 2000; Patton, 2014:505; Yıldırım ve Şimşek, 2013:236) ve içerik analizi (Patton, 2014:453; Yıldırım ve Şimşek, 2013:259-272) teknikleri kullanılarak her 
metafor ayrıştııımış ve diğer metaforlarla olan benzerlikleri veya ortak özellikleri bakımından analiz edilmiştir.

Forceville (1996), herhangi bir şeyin metafor olarak kabul görmesi için en az şu üç sorunun yanıtlanması gerektiğini ifade etmiştir (Akt: Forceville, 2002:2) Bunlar: "1- Metaforun konusu nedir? 2- Metaforun kaynağı nedir? 3-Metaforun kaynağından konusuna atfedilmesi düşünülen özellikler nelerdir?" Bu amaç için katılımcıların kaleme aldıkları metaforlar tekrar tek tek okunup gözden geçirilerek, her metafor imgesi (1) metaforun konusu, (2) metaforun kaynağı ve (3) metaforun konusu ile metaforun kaynağı arasındaki ilişki bakımlarından analiz edilmiştir.

Çalışma grubunda yer alan 285 katılımcının etkinlik kâğıtları metafor ve gerekçeleri ile birlikte sıra numaralarına göre listelenmiştir. Bu araştırmada elenen toplam 27 katııım formundan, 7 tanesi boş bırakıldığı, 20 tanesi de tamamlanmış herhangi bir metafor içermediğinden dolayı araştırma kapsamı dışında tutulmuştur.

Ayıklanma süreci başlıca dört kritere dayalı olarak gerçekleştirildi: (a) sadece tanımlamaların yapıldığı veya herhangi bir metafor kaynağını içermeyen kağıtlar, (b) belli bir metafordan söz edilmesine rağmen metafor için herhangi bir gerekçenin sunulmadığı kağıtlar, (c) birden fazla kategoriye ait özellikleri içeren metaforlar ve (d) "evrensel" değerlerinin daha iyi anlaşılmasına herhangi bir katkısı olmayan metaforlar.

Elenen kâğıtlardan örnekler verilecek olunursa; katılımcılardan bir tanesi "Özgürlük kuş gibidir. Çünkü serbest bırakılınca artar." şeklindeki açıklamasıyla metaforun konusu ile metaforun kaynağı arasındaki ilişki bakımından anlamlı bulunamadığı için elenmiştir. Bundan başka, "Sorumluluk, kanat gibidir. Çünkü .........", "Özgürlük, dil gibidir. Çünkü ........", şeklinde metaforun kaynağı belirtilmemiş ve elenmiştir.

Katılımcıların kendi el yazılarıyla kaleme aldıkları metafor ifadesinin çok uzun olduğu durumlarda, katılımcıların kendi sözcükleri ve anlatım dili korunarak metaforun sadece en çarpıcı boyutları aktarılmıştır. Bir metafor ifadesinin kimin tarafından üretildiğine ilişkin kişisel bilgiler, söz konusu metafor ifadesinin hemen sonundaki parantez içinde kodlanmıs olarak verilmektedir. Bu kodların anlamları şunlardır: "̈̈" öğretmen ve "ÖA" öğretmen adayını, cinsiyet için " $\boldsymbol{E}$ " erkek ve " $\boldsymbol{K}$ " kadın, en sondaki sayı ise kaçıncı kişi olduklarını belirtmek için kullanılmıştır. Örneğin; ÖE2 (Sosyal Bilgiler Erkek Öğretmen 2. kişi), ÖA4K34 (Sosyal Bilgiler 4.Sınıf Kadın Öğretmen Adayı 34.Kişi)

\section{c. Kategori Geliştirme Aşaması:}

Bu aşamada, temel olarak katııımcılar tarafından üretilen metaforların, "Evrensel değerlere" ilişkin sahip oldukları ortak özellikler yönüyle incelenmesi hedeflenmiştir. Bu amaç doğrultusunda öncelikle, özellikle ikinci aşamada örnek metafor listesi baz alınıp her metafor imgesi incelenmiş ve belli bir kodla ilişkilendirilerek, her değer için farklı sayıda toplamda 233 öğretmen adayları metaforları için 32, 40 öğretmenin metaforları için ise 27 farklı kavramsal kategori oluşturulmuştur.

\section{d. Geçerlik ve Güvenirliği Sağlama Așaması:}

Geçerlik ve güvenirlik, araştırma sonuçlarının inandırıcılığını artırmak için araştırmalarda en yaygın olarak kullanılan iki ölçüttür (Yıldırım ve Şimşek, 2013:288). Araştırma sonuçlarının geçerliliğini sağlamada iki önemli süreç gerçekleştirilmiştir. (a) Veri analiz süreci detaylı bir şekilde açıklanmıştır. (b) Bulguların işlenmesinde ve yorumlanmasında öğrencilerin kendi el yazıları ile yazdıkları metafor imgeleri, temel veri kaynağı olarak kullanılarak her kavramsal kategoriyi oluşturan alt özelliklerin her biri en az bir öğrenci metafor imgesiyle (yani doğrudan alıntılarla) desteklenmiştir.

Araştırmanın (iç) güvenirliğini sağlamak için de iki araştırmacı araştırmanın başından sonuna kadar her aşamada (örneğin, araştırma deseninin oluşturulması, araştırma sorularının yazılması, verilerin toplanması, kavramsal metafor kategorilerinin geliştirilmesi ve sonuçların 
yorumlanması aşamalarında) uyum içinde çalışarak birlikte hareket etmiştir. Daha sonra, bu iki araştırmacının yaptığı eşleştirmeler kendi kategorileriyle karşılaştırılmıştır. Bütün karşılaştırmalarda görüş birliği ve görüş ayrılığı sayıları tespit edilerek, araştırmanın (iç) güvenilirliği Miles ve Huberman'ın (1994:64) formülü (Güvenirlik=Görüş Birliği / Görüş Birliği+Görüş Ayrılığı) kullanılarak hesaplanmıştır. Miles ve Huberman'a (1994:64) göre, uzman ve araştırmacı değerlendirmeleri arasındaki uyumun \%90'a yaklaşması ya da \%90'ı geçmesi durumunda arzu edilen düzeyde bir güvenilirlik sağlanmış olmaktadır. Bu araştırmaya özgü olarak gerçekleştirilen güvenirlik çalışmasında sırasıyla öğretmen metaforları için \%94 ve öğretmen adayları metaforları için \%92 oranlarında bir uzlaşma sağlanmıştır.

\section{e. Nicel Veri Analizi için Verileri SPSS Paket Programına Aktarma Aşaması}

Bütün veriler SPSS istatistik programına aktarıldıktan sonra, ilk olarak her bir metaforu ve kategoriyi temsil eden öğrenci sayısı ( $f$ ) ve yüzdesi (\%) hesaplanmıştır.

\section{BULGULAR}

Bu bölümde ilk olarak araştırmada elde edilen sosyal bilgiler öğretmenlerinin ve sosyal bilgiler öğretmen adaylarının ve "evrensel değerlere" ilişkin ileri sürdükleri metaforlara değinilmektedir. Daha sonra, "evrensel değerlere" ilişkin olarak araştırmada elde edilen metaforlarla öğretmen adayları metaforları için 32, öğretmenlerin metaforları için ise 27 farklı kategori, katıımcıların ürettiği örnek metaforlarla desteklenerek açıklanmıştır. Toplam metafor sayısını içeren tablolar uzun olup fazla yer kapladığı için bu tablolara ilişkin bulgulara sözel olarak yer verilmiş olup sadece kategorileri içeren tablolara yer verilmiştir.

217 öğretmen adayı 9 değer için toplamda birbirinden farklı olarak 233 metafor geliştirmiştir. En çok dürüstlük değeri için 59, en az ise bilimsellik değeri için 32 metafor geliştirilmiş olup sevgi değeri için 48 , özgürlük değeri için 41 , yardımseverlik değeri için 40 , saygı değeri için 35 , vatanseverlik değeri için 34 , barış ve sorumluluk değerleri için ise 33 , farklı mefafor geliştirilmiş̧ir. En çok geliştirilen metafor özgürlük değeri için kuş (106) metaforu olup, barış değeri için çocuk (38) ve gülümseme (17); bilimsellik değeri için uzay (25) ve kitap (17); dürüstlük değeri için ayna (29) ve çocuk (19); özgürlük değeri için kuş (106) ve gökyüzü (16); saygı değeri için baba (25) ve maymuncuk (17); sevgi değeri için anne (28) ve güneş (25); sorumluluk değeri için baba (25) ve anne (20); vatanseverlik değeri için aşk (34) ve namus (26); yardımseverlik değeri için ise baba (20) ve güneş (17) metaforları en çok geliştirilen metaforlardır. Güneş metaforu özgürlük ve vatanseverlik değerleri dışında; su metaforu ise bilimsellik ve sorumluluk, aşk metaforu sevgi ve yardımseverlik değerleri dışında tüm değerler için ortak olarak üretilmiş metaforlardır.

40 öğretmen 9 değer için toplamda birbirinden farklı olarak 68 metafor geliştirmiştir. En çok dürüstlük değeri için 17, en az ise bilimsellik ve sorumluluk değeri için 8 metafor geliştirilmiş olup sevgi değeri için 15 , yardımseverlik değeri için 13, barış ve saygı değeri için 11, özgürlük ve vatanseverlik değeri için ise 9 farklı mefafor geliştirilmiştir. En çok geliştirilen metafor özgürlük değeri için kuş (18) metaforu olup, barış değeri için aşk ve beyaz güvercin (7) ; bilimsellik değeri için meşale (9) ve deney (8); dürüstlük değeri için çocuk ve göz (5); özgürlük değeri için kuş (18) ve hava (8); saygı değeri için altın (11) ve maymuncuk (7); sevgi değeri için anne (9) ve su (7); sorumluluk değeri için güneş (9) ve anne (8); vatanseverlik değeri için evlat (7) aşk ve namus (6); yardımseverlik değeri için ise çimento (7) ve güneş (5) metaforları en çok geliştirilen metaforlardır. Öğretmen adaylarında olduğu gibi değerler için ortak olarak üretilmiş olan metafor fazla olmayıp bilimsellik, dürüstlük, saygı, sorumluluk, yardımseverlik olmak üzere 5 değer için güneş; barış, bilimsellik, dürüstlük, sorumluluk, vatanseverlik olmak üzere 5 değer için namus; barış, dürüstlük, özgürlük, sevgi olmak üzere 4 değer için su metaforları geliştirilmişken sevgi, sorumluluk, yardımseverlik, vatanseverlik olmak üzere 4 değer için ise kalp metaforları geliştirilmiştir. 


\section{Tablo 2.}

"Barış" Değerine Yönelik Geliştirilen Metaforların Kategorilere Göre Dağılımları

\begin{tabular}{|c|c|c|c|c|c|c|}
\hline \multirow{2}{*}{ Kategoriler } & \multicolumn{3}{|l|}{ Sosyal Bilgiler Öğretmen Adayları } & \multicolumn{3}{|c|}{ Sosyal Bilgiler Öğretmenleri } \\
\hline & Metaforlar & $f$ & $\%$ & Metaforlar & $f$ & $\%$ \\
\hline $\begin{array}{l}\text { 1.Masumiyet } \\
\text { sembolü olmaya } \\
\text { yönelik }\end{array}$ & $\begin{array}{l}\text { Çocuk (38), Beyaz güvercin (16), Güvercin } \\
\text { (8), Peygamberimiz (3) }\end{array}$ & 65 & 30 & $\begin{array}{c}\text { Beyaz } \\
\text { güvercin (7) } \\
\text { Zeytin dalı (3) } \\
\text { Çocuk (2) }\end{array}$ & 12 & 30 \\
\hline $\begin{array}{l}\text { 2.Huzur ve } \\
\text { mutluluk } \\
\text { vermeye yönelik }\end{array}$ & $\begin{array}{l}\text { Gülümseme (17), Gökyüzü (10), Mutluluk } \\
\text { (7), Bayram (4), Çiçek (4), Para (3), Yaşam } \\
\text { (3), Gökkuşağı (2), Anne Şefkati (2), Aşk } \\
\text { (2), Yeşil (1) }\end{array}$ & 55 & 25 & $\begin{array}{l}\text { Aşk (7) } \\
\text { Misk (2) } \\
\text { Pasta (1) }\end{array}$ & 10 & 25 \\
\hline $\begin{array}{l}\text { 3.Birlik, } \\
\text { beraberlik } \\
\text { içinde olmaya } \\
\text { yönelik }\end{array}$ & $\begin{array}{l}\text { Kardeşlik (12), Bayram (8), Evren (8), } \\
\text { Deniz (5), Çiçek (4), Orman (3), Cennet (1) }\end{array}$ & 41 & 19 & Kardeş (4) & 4 & 10 \\
\hline $\begin{array}{l}\text { 4.Faydalı olmaya } \\
\text { yönelik }\end{array}$ & $\begin{array}{l}\text { Ağaç (13), Güneş (9), Doğa (3), Çiçek (2), } \\
\text { Kaktüs (2), Merhem (1) }\end{array}$ & 30 & 14 & İlaç (2) & 2 & 5 \\
\hline $\begin{array}{l}\text { 5.İhtiyaç } \\
\text { karşılamaya } \\
\text { yönelik }\end{array}$ & $\begin{array}{l}\text { Su (12), Ekmek (4), Maymuncuk (3), } \\
\text { Yağmur (3), Başparmak (1), Mum (1), } \\
\text { Bayrak (1), Kağnı (1) }\end{array}$ & 26 & 12 & $\begin{array}{l}\text { Su (7) } \\
\text { Hava (3) } \\
\text { Nefes (2) }\end{array}$ & 12 & 30 \\
\hline Toplam & & 217 & 100 & Toplam & 40 & 100 \\
\hline
\end{tabular}

Tablo 2'ye göre, 217 öğretmen adayı 33 metafor, 40 öğretmen ise 11 metafor geliştirmiş ve bu metaforlar 5 kategori altında toplanmıştır. Buna göre öğretmen adayları tarafından en fazla "Masumiyet sembolü olmaya yönelik" kategorisinde ( $f: 65, \% 30)$ metafor geliştirilirken, en az ise "Ihtiyaç karşılamaya yönelik" kategorisinde (f:26, \%12) metafor geliştirilmiştir. Öğretmenler tarafından en fazla "Masumiyet sembolü olmaya yönelik ve ihtiyaç karşılamaya yönelik" kategorilerinde ( $f: 12, \% 30)$ metafor geliştirilirken, en az ise "Faydalı olmaya yönelik" kategorisinde $(f: 2, \% 5)$ metafor geliştirilmiştir. Kategorilerin oluşmasında etkili olan öğretmen ve adaylarının tanımlamalarına ilişkin dikkat çekici bazı ifadeler aşağıda verilmiştir:

"Barış su gibidir. Çünkü su nasıl ki bizim en önemli ihtiyacımızı karşılayarak hayatta kalmamızı sağlıyorsa barış da yaşamın devamını sağlar." (ÖE8)

"Barış kardeş gibidir. Çünkü, kardeş bir olmanın beraber olmanın göstergesidir. Barış içinde olunca beraberliğimiz daim olur" (ÖE9)

"Barış gökyüzü gibidir. Çünkü, insanlar huzur ve barış içinde yaşar ve masmavi gökyüzüne baktıkça içi rahatlar huzur dolar. Barış ortamında da insan huzurlu olur." (ÖA4E28)

"Barış orman gibidir. Çünkü ormandaki ağaçlar şekli, boyutu ve türü ne olursa olsun bir arada büyür. Barış ortamı da herkesin uyum içinde olmasıdır." (ÖA3E5)

"Barış çocuk gibidir. Çünkü bir çocuğun gözlerine baktığımızda o saf ve masumluğu hissederiz. Kimseye karşı kin ve nefret duymadan sadece barış, huzur ve masumiyet duygularını taşır" (ÖA3K37) 


\section{Tablo 3}

"Bilimsellik" Değerine Yönelik Geliştirilen Metaforların Kategorilere Göre Dağılımları

\begin{tabular}{|c|c|c|c|c|c|c|}
\hline \multirow{2}{*}{ Kategoriler } & \multicolumn{3}{|c|}{ Sosyal Bilgiler Öğretmen Adayları } & \multicolumn{3}{|c|}{ Sosyal Bilgiler Öğretmenleri } \\
\hline & Metaforlar & $f$ & $\%$ & Metaforlar & $f$ & $\%$ \\
\hline $\begin{array}{l}\text { 1.Aydınlatmaya } \\
\text { yönelik }\end{array}$ & $\begin{array}{l}\text { Güneş (15), Meşale (15), Işıı (12), } \\
\text { Ampül (6), Ay (4), Cam (4), Yıldız (3) }\end{array}$ & 59 & 27 & $\begin{array}{l}\text { Meşale (9), } \\
\text { Güneş (3) }\end{array}$ & 12 & 30 \\
\hline $\begin{array}{l}\text { 2.Uçsuz, bucaksız } \\
\text { olmaya yönelik }\end{array}$ & $\begin{array}{l}\text { Uzay (25), Gökyüzü (15), Deniz (5), } \\
\text { Okyanus (3), Merak (2), Hayaller (1) }\end{array}$ & 51 & 24 & $\begin{array}{l}\text { Uzay (6) } \\
\text { Okyanus (4) }\end{array}$ & 10 & 25 \\
\hline $\begin{array}{l}\text { 3. Hassas olmaya } \\
\text { yönelik }\end{array}$ & $\begin{array}{l}\text { Matematik (13), İlaç (12), Beyin Cerrahı } \\
\text { (9), Mikroskop (2), Aşk (1), Laboratuvar } \\
\text { (1) }\end{array}$ & 38 & 18 & $\begin{array}{l}\text { Deney (8) } \\
\text { İlaç (6) }\end{array}$ & 14 & 35 \\
\hline $\begin{array}{l}\text { 4.Yaşamı } \\
\text { kolaylaştırmaya } \\
\text { yönelik } \\
\end{array}$ & $\begin{array}{l}\text { Pusula (14), Köprü (12), Bilgisayar (5), } \\
\text { Teknoloji (3), Baraj (1), Japonya (1), } \\
\text { Meyve Ağacı (1), Tübitak (1) }\end{array}$ & 38 & 18 & $\begin{array}{l}\text { Pusula (2) } \\
\text { Teknoloji (2) }\end{array}$ & 4 & 10 \\
\hline $\begin{array}{l}\text { 5.Güncel, } \\
\text { geliştirilebilir ve } \\
\text { eleştirilebilir } \\
\text { olmaya yönelik }\end{array}$ & $\begin{array}{l}\text { Kitap (17), Apartman (5), Felsefe (5), } \\
\text { Eğitim (3), Teleskop (1) }\end{array}$ & 31 & 14 & - & - & - \\
\hline Toplam & & 217 & 100 & Toplam & 40 & 100 \\
\hline
\end{tabular}

Tablo 3'e göre, 217 öğretmen adayı tarafından geliştirilen 32 metafor 5 kategori altında, 40 öğretmen tarafından geliştirilen 8 metafor ise 4 kategori altında toplanmıştır. Buna göre öğretmen adayları tarafından en fazla "Aydınlatmaya yönelik" kategorisinde (f:59, \%27) metafor geliştirilirken, en az ise "Güncel, geliştirilebilir ve eleştirilebilir olmaya yönelik" kategorisinde ( $f: 31$, \%12) metafor geliştirilmiştir. Öğretmenler tarafından en fazla "Hassas olmaya yönelik" kategorilerinde (f:14, \%35) metafor geliştirilirken, en az ise "Yaşamı kolaylaştırmaya yönelik" kategorisinde $(f: 4, \% 10)$ metafor geliştirilmiştir. Kategorilerin oluşmasında etkili olan öğretmen ve adaylarının tanımlamalarına ilişkin dikkat çekici bazı ifadeler aşağıda verilmiştir:

"Bilimsellik deney gibidir. Çünkü deneyle gerçeği buluruz. Bilimsellikle de doğruyu yanlışı tespit ederiz" (ÖE2)

"Bilimsellik güneş gibidir. Çünkü güneş nasıl ışığıyla insanlığa hayat oluyorsa bilimde insanlığa hizmet eder "(ÖK9).

"Bilimsellik meşale gibidir. Çünkü karanlığı ancak bilimle aydınlatırsın". (ÖE3)

"Bilimsellik pusula gibidir. Çünkü pusula sayesinde doğru yolu buluruz. Bilimsel çalışmalardan elde edilen sonuçlarda bizleri doğru yola ulaştırır" (ÖA2K28)

"Bilimsellik felsefe gibidir. Çünkü sürekli yeni ve araştırmaya açık, eleştirilebilir bilgiler vardır." (ÖA3E12)

"Bilimsellik uzay gibidir. Çünkü uzayın sonu yoktur. Her gün yeni galaksiler yeni yıldızlar keşfedilmekte. Bilimde de her gün yeni şeyler ortaya çıkarılmakta" (ÖA1K5) "Bilimsellik ışık gibidir. Çünkü, insanı aydınlatır, gerçekleri, farklılıkları yeni dünyaları görmesini sağlar" (ÖA1K13) 


\section{Tablo 4}

"Dürüstlük" Değerine Yönelik Geliştirilen Metaforların Kategorilere Göre Dağıımları

\begin{tabular}{|c|c|c|c|c|c|c|}
\hline \multirow{2}{*}{ Kategoriler } & \multicolumn{3}{|c|}{ Sosyal Bilgiler Öğretmen Adayları } & \multicolumn{3}{|c|}{ Sosyal Bilgiler Öğretmenleri } \\
\hline & Metaforlar & $f$ & $\%$ & Metaforlar & $f$ & $\%$ \\
\hline $\begin{array}{l}\text { 1.Her zaman } \\
\text { doğruyu } \\
\text { göstermeye } \\
\text { yönelik }\end{array}$ & $\begin{array}{l}\text { Ayna (29), Çocuk (19), Kalem (3), } \\
\text { Fotoğraf Makinesi (2), Bebek (1), Saat } \\
\text { (1) }\end{array}$ & 55 & 25 & $\begin{array}{l}\text { Çocuk (5) } \\
\text { Göz (5) } \\
\text { Ayna (2) } \\
\text { Saat (2) }\end{array}$ & 14 & 35 \\
\hline 2.Şeffaflığa yönelik & $\begin{array}{l}\text { Su (18), Karakter (8), Beyaz renk (7), } \\
\text { Cam (5), Aşk (2), Şeffaf Kâğıt (2), Terazi } \\
\text { (2), Adalet (1), Hâkim (1) }\end{array}$ & 46 & 21 & $\begin{array}{l}\text { Su (2) } \\
\text { Cam (1) }\end{array}$ & 3 & 7,5 \\
\hline $\begin{array}{l}\text { 3.Yol göstermeye } \\
\text { yönelik }\end{array}$ & $\begin{array}{l}\text { Baba (7), Harita (7), Din (4), Pusula (4), } \\
\text { Hz. Ömer (3), Meşale (3), } \\
\text { Peygamberimiz (3), Aile (1), Ay (1), } \\
\text { İslam (1), Kur'an-ı Kerim (1), Mevlâna } \\
\text { (1), Yıldız (1) }\end{array}$ & 37 & 17 & $\begin{array}{l}\text { Baba (4) } \\
\text { Hz. Ömer (3) } \\
\text { Pusula (1) }\end{array}$ & 8 & 20 \\
\hline $\begin{array}{l}\text { 4.Faydalı olmaya } \\
\text { yönelik }\end{array}$ & $\begin{array}{l}\text { Güneş (11), Ağaç (6), Çınar ağacı (3), } \\
\text { Kitap (3), Arı (2), Deniz (2) }\end{array}$ & 27 & 12 & Güneş (2) & 2 & 5 \\
\hline $\begin{array}{l}\text { 5.Nadir olmaya } \\
\text { yönelik }\end{array}$ & $\begin{array}{l}\text { Altın (6), Vicdan (5), Hazine (4), Elmas } \\
\text { (2), İnci (2), Değerli Maden (2), } \\
\text { Fedakârlık (1), Nesli tükenen tür (1) } \\
\text { Pırlanta (1) }\end{array}$ & 24 & 11 & $\begin{array}{l}\text { Hazine (3) } \\
\text { Altın (2) } \\
\text { Maymuncuk } \\
(2)\end{array}$ & 7 & 17,5 \\
\hline $\begin{array}{l}\text { 6.Kategoriye } \\
\text { Girmeyenler }\end{array}$ & $\begin{array}{l}\text { Dağ (4), Bulut (1), Bumerang (1), Çanak } \\
\text { Anten (1), Hırka (1), Karlı dağ (1), Ok } \\
\text { (1), Portakal (1), Puzzle (1), Süzme } \\
\text { yoğurt (1), Tohum (1), Yay (1) }\end{array}$ & 15 & 7 & $\begin{array}{l}\text { Ok (2) } \\
\text { Cetvel (1) }\end{array}$ & 3 & 7,5 \\
\hline $\begin{array}{l}\text { 7.Olması gereken } \\
\text { duruma yönelik }\end{array}$ & $\begin{array}{l}\text { Gölge (4), Temel (4), Sıfır rakamı (3), } \\
\text { Nefes (2) }\end{array}$ & 13 & 6 & $\begin{array}{l}\text { Nefes (2) } \\
\text { Tuz (1) }\end{array}$ & 3 & 7,5 \\
\hline Toplam & & 217 & 100 & Toplam & 40 & 100 \\
\hline
\end{tabular}

Tablo 4'e göre, 217 öğretmen adayı 59 metafor, 40 öğretmen ise 17 metafor geliştirmiş ve bu metaforlar 6 kategori altında toplanmıştır. Buna göre öğretmen adayları tarafından en fazla "Her zaman doğruyu göstermeye yönelik" kategorisinde $(f: 55, \% 25)$ metafor geliştirilirken, en az ise "Olması gereken duruma yönelik" kategorisinde ( $f: 13, \% 6)$ metafor geliştirilmiştir. Öğretmenler tarafından en fazla "Her zaman doğruyu göstermeye yönelik" kategorisinde (f:14, \%35) metafor geliştirilirken, en az ise "Faydalı olmaya yönelik" kategorisinde (f:2, \%5) metafor geliştirilmiştir. Kategorilerin oluşmasında etkili olan öğretmen ve adaylarının tanımlamalarına ilişkin dikkat çekici bazı ifadeler aşağıda verilmiştir:

"Dürüstlük göz gibidir. Çünkü, göz neyi görürse beyne onu iletir. Asla yalan söylemez.

Dürüstlükle olan bir şeyi olduğu gibi aktarmaktır." (ÖK5)

"Dürüstlük cam gibidir. Çünkü, camın önünü arkasını görürüz. Dürüstlükte içi dışı bir olmaktır" (ÖE10)

"Dürüstlük yıldı gibidir. Çünkü, karanlık çöktügünde belirirler ve aydınlığı ortaya çıkarırlar. Dürüstlükte her şeyi aydınlatır." (ÖA2K17)

"Dürüstlük terazi gibidir. Çünkü terazi nasıl ki tarttığı şeyleri olduğu gibi gösteriyorsa yalan yanlış yoksa dürüstlükte de yoktur." (ÖA2K12)

"Dürüstlük pusula gibidir. Çünkü, pusula nasıl ki insana yoluna şaşırtmaz doğruyu gösterir ise dürüstlükte insana doğruyu buldurur." (ÖA3K21)

"Dürüstlük İlam gibidir. Çünkü, doğru şeyler yaptığında mükafatlandırır yanlış şeyler yaptığında ise cezalandırır" (ÖA2K1) 
"Dürüstlük puzzle gibidir. Çünkü her doğru parça sana mükemmel bir tablo sunar. Dürüstlükte her doğru söylediğinde benliğini kuvvetlendirir" (ÖA2K11)"

\begin{tabular}{|c|c|c|c|c|c|c|}
\hline \multicolumn{7}{|l|}{$\begin{array}{l}\text { Tablo } 5 \\
\text { "Özgürlü }\end{array}$} \\
\hline \multirow{2}{*}{ Kategoriler } & \multicolumn{3}{|c|}{ Sosyal Bilgiler Öğretmen Adayları } & \multicolumn{3}{|c|}{ Sosyal Bilgiler Öğretmenleri } \\
\hline & Metaforlar & $f$ & $\%$ & Metaforlar & $f$ & $\%$ \\
\hline $\begin{array}{l}\text { 1.Engellerin } \\
\text { olmamasına } \\
\text { yönelik }\end{array}$ & $\begin{array}{l}\text { Kuş (101), Hayal (5), Kartal (3), Balon } \\
\text { (2), Kurt (2), Amerika (1), Aslan (1), Aşk } \\
\text { (1), Balık (1), Çiçek (1), Kelebek (1), On } \\
\text { sekiz yaş (1), Silah (1), Şairin Kalemi (1) }\end{array}$ & 122 & 56 & Kuş (18) & 18 & 45 \\
\hline $\begin{array}{l}\text { 2.Uçsuz, bucaksız } \\
\text { olmaya yönelik }\end{array}$ & $\begin{array}{l}\text { Gökyüzü (16), Deniz (6), Okyanus (6), } \\
\text { Uzay (2), Çöl (1) }\end{array}$ & 31 & 14 & Gökyüzü (3) & 3 & 7,5 \\
\hline $\begin{array}{l}\text { 3.Olması gereken } \\
\text { duruma yönelik }\end{array}$ & $\begin{array}{l}\text { Nefes (14), Yaşam (6), Su (3), Eğitim (2), } \\
\text { Oyun (2), Ekmek-su (1), Kalp (1) }\end{array}$ & 29 & 13 & $\begin{array}{l}\text { Hava (8), Su } \\
\text { (4), Gölge } \\
\text { (1) } \\
\end{array}$ & 13 & 32,5 \\
\hline $\begin{array}{l}\text { 4.Temsiliyete } \\
\text { yönelik }\end{array}$ & $\begin{array}{l}\text { Kuş (5), Vatan (4), Bayrak (3), Barış (2), } \\
\text { Kurtuluş Savaşı (2), Altın (1), İslam (1), } \\
\text { İstiklal Marşı (1), Nar (1) }\end{array}$ & 20 & 9 & - & - & - \\
\hline $\begin{array}{l}\text { 5.Sınırları bilmeye } \\
\text { yönelik }\end{array}$ & $\begin{array}{l}\text { Balon (3), Çikolata (3), Atmosfer (2), } \\
\text { Muhabbet kuşu (2), Uçurtma (2), } \\
\text { Bardak (1), Futbol maçı (1), Kalem (1) }\end{array}$ & 15 & 7 & $\begin{array}{l}\text { Arı (2), } \\
\text { Bebek (2), } \\
\text { Anahtar (1), } \\
\text { Kar tanesi } \\
(1)\end{array}$ & 6 & 15 \\
\hline & Toplam & 217 & 100 & Toplam & 40 & 100 \\
\hline
\end{tabular}

Tablo 5'e göre, 217 öğretmen adayı tarafından geliştirilen 41 metafor 5 kategori altında, 40 öğretmen tarafından geliştirilen 9 metafor ise 4 kategori altında toplanmıştır. Buna göre öğretmen adayları tarafından en fazla "Engellerin olmamasına yönelik" kategorisinde ( $f: 122, \% 56)$ metafor geliştirilirken, en az ise "Sınırları bilmeye yönelik" kategorisinde ( $f: 15, \% 7)$ metafor geliştirilmiştir. Öğretmenler tarafından en fazla "Engellerin olmamasına yönelik" kategorisinde (f:18, \%45) metafor geliştirilirken, en az ise "Uçsuz, bucaksız olmaya yönelik" kategorisinde ( $f: 3$, $\% 7,5)$ metafor geliştirilmiştir. Kategorilerin oluşmasında etkili olan öğretmen ve adaylarının tanımlamalarına ilişkin dikkat çekici bazı ifadeler aşağıda verilmiştir:

"Özgürlük kuş gibidir. Çünkü kuşlar sınır tanımazlar gökyüzü onlarındır. Özgürlükte sınır tanımamaktır. (ÖE15)"

"Özgürlük gökyüzü gibidir. Çünkü gökyüzünün ucu bucağı yoktur. Özgürlüklerinde sonu yoktur. Kimseleri rahatsız etmemek şartılla sonsuzdur. (ÖK11)"

"Özgürlük kar taneleri gibidir. Çünkü kar taneleri birbirine değmeden yere düşer. Hem dilediği gibi yere düşer hem de birbirlerinin alanına girmezler. (ÖK5)"

"Özgürlük kuş gibidir. Çünkü kuşlar hiçbir kurala ya da hiçbir duruma bağlı olmadan istedikleri yönde uçarlar. Kuş için engel yok gibidir. Özgürlükte engellerin ortadan kalkması gibidir. (ÖA4K22)"

"Özgürlük yaşam gibidir. Çünkü nerede başlayıp nerede biteceği belli olmaz. (ÖA2K10)" 
"Özgürlük uçurtma gibidir. Çünkü uçurtmanın ipini başkasının elindedir. O kişinin izin verdiği yerlere ulaşabilir. Özgürlüklerimiz başkalarının bizlere tanıdığı haklar kadardır. (ÖA1K16)"

"Özgürlük çikolata gibidir. Çünkü çikolata çok tatıdır ama fazlası zarar verir. Özgürlükte iyidir ama fazlası başta kişinin kendisine zarar verir. (ÖA4K21)"

"Özgürlük hayal gibidir. Çünkü önüne engel koyulmazsa sonuna kadar gidilir. Konulursa sınırlandırllır. (ÖA2K1)"

\section{Tablo 6}

"Saygı" Değerine Yönelik Geliştirilen Metaforların Kategorilere Göre Dağılımları

\begin{tabular}{|c|c|c|c|c|c|c|}
\hline \multirow{2}{*}{ Kategoriler } & \multicolumn{3}{|c|}{ Sosyal Bilgiler Öğretmen Adayları } & \multicolumn{3}{|c|}{ Sosyal Bilgiler Öğretmenleri } \\
\hline & Metaforlar & $f$ & $\%$ & Metaforlar & $f$ & $\%$ \\
\hline $\begin{array}{l}\text { 1.Karşılıksız } \\
\text { olmaya yönelik }\end{array}$ & $\begin{array}{l}\text { Baba (22), Aile (14), Namaz (6), } \\
\text { Peygamberimiz (5), Martin Luther King } \\
\text { (1) }\end{array}$ & 48 & 22 & - & & \\
\hline $\begin{array}{l}\text { 2.Ayrım } \\
\text { yapmamaya }\end{array}$ & $\begin{array}{l}\text { Maymuncuk (17), Beyin (10), Güneş (6), } \\
\text { Örtü (5), Ayna (4) }\end{array}$ & 42 & 19 & $\begin{array}{l}\text { Maymuncuk } \\
\text { (7) } \\
\text { Güneş (3) }\end{array}$ & 10 & 25 \\
\hline $\begin{array}{l}\text { 3.Olmazsa olmaza } \\
\text { yönelik }\end{array}$ & $\begin{array}{l}\text { Gölge (12), Kar tanesi (7), Binanın } \\
\text { temeli (6), Kalp (6), Kök (5), Su (2), } \\
\text { Gece-gündüz (1), Vicdan (1) }\end{array}$ & 40 & 18 & - & & \\
\hline $\begin{array}{l}\text { 4.Menfaate- } \\
\text { koşula yönelik }\end{array}$ & $\begin{array}{l}\text { Aşk (12), Toprak (8), Asker (4), Baba (3), } \\
\text { Çocuk (3), Kardeş (2), Ağaç (1) }\end{array}$ & 33 & 15 & $\begin{array}{l}\text { Hiyerarşi (2) } \\
\text { Toprak (2) }\end{array}$ & 4 & 10 \\
\hline $\begin{array}{l}\text { 5.Değerini } \\
\text { arttırmaya yönelik }\end{array}$ & Kitap (12), Tuz (6), Şeker (4) & 22 & 10 & $\begin{array}{l}\text { Altın (11), } \\
\text { Yeni gelin } \\
(2)\end{array}$ & 13 & 32,5 \\
\hline $\begin{array}{ll}\text { 6.Devamı } & \text { sağlayıp } \\
\text { ayakta } & \text { kalmaya } \\
\text { yönelik } & \end{array}$ & İskelet (12), Aslan (7), Kanun (2) & 21 & 10 & $\begin{array}{l}\text { Bayram (4), } \\
\text { Köprü (4), } \\
\text { Aslan (2), } \\
\text { İskelet (2) }\end{array}$ & 12 & 30 \\
\hline $\begin{array}{l}\text { 7.Kategoriye } \\
\text { girmeyen }\end{array}$ & $\begin{array}{l}\text { Merdiven (3), Akrep ile Yelkovan (2), } \\
\text { Antika (2), Dağ (2), Ağaç (1), Ayçiçeği } \\
\text { (1) }\end{array}$ & 11 & 5 & $\begin{array}{l}\text { Patlamış } \\
\text { mısır (1) }\end{array}$ & 1 & 2,5 \\
\hline Toplam & & 217 & 100 & Toplam & 40 & 100 \\
\hline
\end{tabular}

Tablo 6'ya göre, 217 öğretmen adayı tarafından geliştirilen 35 metafor 6 kategori altında, 40 öğretmen tarafından geliştirilen 11 metafor ise 4 kategori altında toplanmıştır. Buna göre öğretmen adayları tarafından en fazla "Karşılıksız olmaya yönelik" kategorisinde (f:48, \%22) metafor geliştirilirken, en az ise "Devamı sağlayıp ayakta kalmaya yönelik" kategorisinde (f:21, \%10) metafor geliştirilmiştir. Öğretmenler tarafından en fazla "Değerini arttırmaya yönelik" kategorisinde ( $f: 13, \% 32,5)$ metafor geliştirilirken, en az ise "Menfaate- koşula yönelik" kategorisinde $(f: 4, \% 10)$ metafor geliştirilmiştir. Kategorilerin oluşmasında etkili olan öğretmen ve adaylarının tanımlamalarına ilişkin dikkat çekici bazı ifadeler aşağıda verilmiştir:

"Saygı bayram gibidir. Çünkü bayramlar insanları nasıl bir arada toplar ve birleştirirse saygı da bir arada yaşama imkânı sağlar. (ÖE16)" 
"Saygı maymuncuk gibidir. Çünkü maymuncuk anahtar ayrım yapmadan her kapıyı açar. İşte saygı da insana her kapıyı açan bir anahtar gibidir. (ÖE11)"

"Saygı toprak gibidir. Çünkü toprağa ne ekersen onu biçersin insanlara da karşı ne kadar saygılı olursan karşılığı da o kadar fazla olur. (ÖA4K22)"

"Saygı kitap gibidir. Çünkü kitap bilgimizi arttırdığı gibi saygı da bizim itibarımızı arttırrr. (ÖA4K24)"

"Saygı iskelet gibidir. Çünkü iskelet vücudun ayakta durmasını sağladığı gibi saygıda toplumun ayakta kalmasını sağlar." (ÖA4K21)

"Saygı aşk gibidir. Çünkü karşılıklı olursa ömür boyu sürer. Karşılıksız olursa bir zaman sonra biter." (ÖA1K19)

\section{Tablo 7}

"Sevgi" Değerine Yönelik Geliştirilen Metaforların Kategorilere Göre Dağılımları

\begin{tabular}{|c|c|c|c|c|c|c|}
\hline \multirow{2}{*}{ Kategoriler } & \multicolumn{3}{|c|}{ Sosyal Bilgiler Öğretmen Adayları } & \multicolumn{3}{|c|}{ Sosyal Bilgiler Öğretmenleri } \\
\hline & Metaforlar & $f$ & $\%$ & Metaforlar & $f$ & $\%$ \\
\hline $\begin{array}{l}\text { 1.Karşılıksız } \\
\text { olmaya yönelik }\end{array}$ & $\begin{array}{l}\text { Anne (28), Aile (15), Güneş (15), Dişi } \\
\text { güvercin (1), Fiskyizm (1) }\end{array}$ & 60 & 28 & $\begin{array}{l}\text { Anne (9), } \\
\text { Baba (2) }\end{array}$ & 11 & 27,5 \\
\hline $\begin{array}{l}\text { 2.Olmazsa olmaza } \\
\text { yönelik }\end{array}$ & $\begin{array}{l}\text { Nefes (15), Su (13), Güneş (8), Kalp (5), } \\
\text { Çay (3), Ruh (2), Ateş (1) }\end{array}$ & 47 & 22 & $\begin{array}{l}\text { Su (7), Kalp } \\
(3), \text { Barış (1) }\end{array}$ & 11 & 27,5 \\
\hline $\begin{array}{l}\text { 3.Menfaate-koşula } \\
\text { yönelik }\end{array}$ & $\begin{array}{l}\text { Çiçek (19), Ağaç (13), Tohum (4), Fidan } \\
\text { (3), Gül (2), Toprak (2), Selvi ağacı (1) }\end{array}$ & 44 & 20 & $\begin{array}{l}\text { Çiçek (4), } \\
\text { Akarsu (2), } \\
\text { Deniz (1), } \\
\text { Toprak (1) } \\
\end{array}$ & 8 & 20 \\
\hline $\begin{array}{l}\text { 4.Uçsuz, bucaksız } \\
\text { olmaya yönelik }\end{array}$ & $\begin{array}{l}\text { Okyanus (10), Gökyüzü (6), Deniz (3), } \\
\text { Irmak (3), Çığ (2), Kartopu (1), Maden } \\
\text { (1), Rüya (1), Sarmaşık (1), Ütopya (1), } \\
\text { Yıldız (1), Yol (1) }\end{array}$ & 31 & 14 & $\begin{array}{l}\text { Deniz (2), } \\
\text { Okyanus (1) }\end{array}$ & 3 & 7,5 \\
\hline $\begin{array}{l}\text { 5.Faydalı olmaya } \\
\text { yönelik }\end{array}$ & $\begin{array}{l}\text { Atkı (2), Güneş (2), İlaç (2), Mum (2), } \\
\text { Telefon (2), Tuz (2), Kalkan (1), Meşale } \\
\text { (1), Soba (1), Yağmur (1), Yorgan (1) }\end{array}$ & 17 & 7 & $\begin{array}{l}\text { İlaç (2), } \\
\text { Yağmur } \\
\text { damlası (1) }\end{array}$ & 3 & 7,5 \\
\hline $\begin{array}{l}\text { 6.Masumiyet } \\
\text { sembolü olmaya } \\
\text { yönelik }\end{array}$ & Bebek (4), Çocuk (4), Su (3), Kelebek (2) & 13 & 6 & - & - & - \\
\hline $\begin{array}{l}\text { 7.Kategoriye } \\
\text { girmeyen }\end{array}$ & $\begin{array}{l}\text { Boş resim defteri (1), Elmas (1), Emanet } \\
(1), \text { Gökkuşağı (1), Pasta (1) }\end{array}$ & 5 & 2 & $\begin{array}{l}\text { Bilgi (2), } \\
\text { Çikolata (1), } \\
\text { Huzur (1) }\end{array}$ & 4 & 10 \\
\hline Toplam & & 217 & 100 & & 40 & 100 \\
\hline
\end{tabular}

Tablo 7'ye göre, 217 öğretmen adayı tarafından geliştirilen 48 metafor 6 kategori altında, 40 öğretmen tarafından geliştirilen 15 metafor ise 5 kategori altında toplanmıştır. Buna göre öğretmen adayları tarafından en fazla "Karşılıksız olmaya yönelik" kategorisinde (f:60, \%28) metafor geliştirilirken, en az ise "Masumiyet sembolü olmaya yönelik" kategorisinde (f:13, \%6) metafor geliştirilmiştir. Öğretmenler tarafından en fazla "Karşılıksız olmaya yönelik ve Olmazsa olmaza yönelik" kategorilerinde $(f: 11, \% 27,5)$ metafor geliştirilirken, en az ise "Uçsuz, bucaksız olmaya yönelik ve Faydalı olmaya yönelik" kategorilerinde $(f: 3, \% 7,5)$ metafor geliştirilmiştir. 
Kategorilerin oluşmasında etkili olan öğretmen ve adaylarının tanımlamalarına ilişkin dikkat çekici bazı ifadeler aşağıda verilmiştir:

"Sevgi anne gibidir. Çünkü anneler sevgi kaynağıdır koşulsuz severler. (ÖE15)"

"Sevgi bilgi gibidir. Çünkü ikisi de paylaşıldıkça çoğalır. (ÖE10)"

"Sevgi çiçek gibidir. Çünkü çiçekler sevildiği, bakıldığı, sulandığı, güneşışığını aldığı ortamlarda yeşerir ve açar. Eğer tüm bunlar ihmal edilirse solar, kurur ve çürür. (ÖE4)"

"Sevgi su gibidir. Çünkü yaşamak için hep muhtacız ona. Insan vücudu fiziksel olarak nasıl ki belli bir zamandan sonra susuzluktan iflas ederse işte sevgisizlikte bitirir insanı. (ÖK12)"

"Sevgi baba gibidir. Çünkü babalar ömürlerini kendilerinden önce ailesinin mutluluğu ve rahatı için ömrünü onlara adar. (ÖE3)"

"Sevgi gökyüzü gibidir. Çünkü belli bir yeri, uzunluğu veya derinliği yoktur. (ÖA2K17)"

"Sevgi boş resim defteri gibidir. Çünkü içini sadece sevgimiz oranında doldurabiliriz. Resme yani sevgiye istediğimiz rengi yapabiliriz. (ÖA3E12)"

"Sevgi anne gibidir. Çünkü anne karşılıksız sever sevgi de karşılıksız olandır. Karşılık beklentisi yoktur. (ÖA3E17)"

"Sevgi yıldız gibidir. Çünkü etrafında ne kadar çok ışık alırsa o kadar çok parlar sevgide ne kadar çok olursa insan mutlu olur. (ÖA3K19)"

\begin{tabular}{|c|c|c|c|c|c|c|}
\hline \multirow{2}{*}{ Kategoriler } & \multicolumn{3}{|c|}{ Sosyal Bilgiler Öğretmen Adayları } & \multicolumn{3}{|c|}{ Sosyal Bilgiler Öğretmenleri } \\
\hline & Metaforlar & $f$ & $\%$ & Metaforlar & $f$ & $\%$ \\
\hline $\begin{array}{l}\text { 1.İşini } \\
\text { aksatmamaya } \\
\text { yönelik }\end{array}$ & $\begin{array}{l}\text { Baba (25), Anne (20), Öğrenci (18), } \\
\text { Güneş (17), Öğretmen (15), } \\
\text { Organlarımız (10), Alarm (6), Borç (4), } \\
\text { Ağaç (3), Anahtar (2), Asker (2), Devlet } \\
\text { (2), Aile (1), Kar tanesi (1), Toprak (1) }\end{array}$ & 127 & 59 & $\begin{array}{ll}\text { Güneş } & (9), \\
\text { Anne } & (8), \\
\text { Beyin } & (6), \\
\text { Baba } & (5), \\
\text { Öğrenci } & (2), \\
\text { Kar tanesi }(2) \\
\end{array}$ & 32 & 80 \\
\hline $\begin{array}{l}\text { 2. Hareket alanını } \\
\text { kısıtlamaya yönelik }\end{array}$ & $\begin{array}{l}\text { Tren (10), Aşk (9), Kelepçe (8), Ağırık } \\
\text { (3), Gemi (1), Set (1) }\end{array}$ & 32 & 15 & - & - & - \\
\hline $\begin{array}{l}\text { 3.Olmazsa olmaza } \\
\text { yönelik }\end{array}$ & $\begin{array}{l}\text { Nefes (11), Hayat (8), Direksiyon (4), } \\
\text { Yaşam (5), Arabanın lastiği (1) }\end{array}$ & 29 & 13 & $\begin{array}{l}\text { Kalp (5), } \\
\text { Nefes (3) }\end{array}$ & 8 & 20 \\
\hline $\begin{array}{l}\begin{array}{l}\text { 4.Bedeli olmaya } \\
\text { yönelik }\end{array} \\
\end{array}$ & Yalan (8), Sınav (6), Nelson Mandela (1) & 15 & 7 & - & - & - \\
\hline $\begin{array}{l}\text { 5.Kategoriye } \\
\text { girmeyen }\end{array}$ & Ezan (5), Bilinç (3) & 8 & 4 & - & - & - \\
\hline $\begin{array}{l}\text { 6.Uçsuz, bucaksız } \\
\text { olmaya yönelik }\end{array}$ & Okyanus (4), Deniz (2) & 6 & 3 & - & - & - \\
\hline & Toplam & 217 & 100 & Toplam & 40 & 100 \\
\hline
\end{tabular}

Tablo 8'e göre, 217 öğretmen adayı tarafından geliştirilen 33 metafor 5 kategori altında, 40 öğretmen tarafından geliştirilen 8 metafor ise 2 kategori altında toplanmıştır. Buna göre öğretmen adayları tarafından en fazla "Işsini aksatmamaya yönelik" kategorisinde ( $f: 127, \% 59)$ metafor geliştirilirken, en az ise "Uçsuz, bucaksı olmaya yönelik" kategorisinde $(f: 6, \% 3)$ metafor geliştirilmiştir. Öğretmenler tarafından ise en fazla "Iş̧ini aksatmamaya yönelik" kategorisinde (f:32, \%80) metafor geliştirilirken en az ise "Olmazsa olmaza yönelik" kategorisinde (f:8, \%20) 
metafor geliştirilmiştir. Kategorilerin oluşmasında etkili olan öğretmen ve adaylarının tanımlamalarına ilişkin dikkat çekici bazı ifadeler aşağıda verilmiştir:

"Sorumluluk baba gibidir. Çünkü babanın eşine, çocuklarına, anne ve babasına, ülkesine karşı yapması gereken görevler vardır. Üstlenmesi gereken birçok görevi vardır. Sorumlulukta insanın hem kendine hem de başkalarına karşı yerine getirmesi gereken şeyleri yapma zorunluluğu vardır. (Ö E4)"

"Sorumluluk anne gibidir. Çünkü ömür boyu çocuklarının yanında olmak, onların sıkıntılarına çare olmak bir anne için bitmeyecek bir görevdir. (ÖK1)"

"Sorumluluk güneş gibidir. Çünkü nasıl güneş kendisine verilen görevi ilk andan itibaren aksatmadan yaparsa dünyamızı hem aydınlatıp hem de ısıtıyorsa bizlerde sorumluluklarımızı yerine getirmeliyiz. (ÖK4)"

"Sorumluluk anne gibidir. Çünkü anne çocuk ve eşine karşı olan vazifelerini aksatmadan yerine getirir. Sorumlulukta üzerine aldığın işi aksatmadan yerine getirmektir. (ÖA3K21)"

"Sorumluluk asker gibidir. Çünkü askerler üstlerine düşen vazifelerini her zaman yerine getirir. Aksatma ve ihmalin sonuçları ağır olur. (ÖA3K5)"

"Sorumluluk ezan gibidir. Çünkü vakti geldiğinde okunarak insanlara yapması gerekenleri hatırlatır. (ÖA1E12)"

\section{Tablo 9}

"Vatanseverlik" Değerine Yönelik Geliştirilen Metaforların Kategorilere Göre Dağılımları

\begin{tabular}{|c|c|c|c|c|c|c|}
\hline \multirow{2}{*}{ Kategoriler } & \multicolumn{3}{|c|}{ Sosyal Bilgiler Öğretmen Adayları } & \multicolumn{3}{|c|}{ Sosyal Bilgiler Öğretmenleri } \\
\hline & Metaforlar & $f$ & $\%$ & Metaforlar & $f$ & $\%$ \\
\hline $\begin{array}{l}\text { 1.Fedakarlığa } \\
\text { yönelik }\end{array}$ & $\begin{array}{l}\text { Anne (25), Mehmetçik (19), Aile (16), } \\
\text { Atatürk (3), Çanakkale (3), Ömer } \\
\text { Halisdemir (2), Hz. Ali (1), Muhsin } \\
\text { Yazıcıoğlu (1), Nene Hatun (1), Şerife } \\
\begin{array}{ll}\text { Bacı (1) } & \end{array}\end{array}$ & 72 & 33 & $\begin{array}{l}\text { Atatürk (3), } \\
\text { Seyit Onbaşı } \\
\text { (2) }\end{array}$ & 5 & 12,5 \\
\hline $\begin{array}{l}\text { 2.Olmazsa } \\
\text { olmaza yönelik }\end{array}$ & $\begin{array}{l}\text { Aşk (34), Nefes (10), Su (10), Temel (4), } \\
\text { Kalp (3), Maya (3), İskelet (2), Elbise (1), } \\
\text { Kolon (1), Vicdan (1) }\end{array}$ & 69 & 32 & $\begin{array}{l}\text { Aşk (6), Kalp } \\
\text { (4), Nefes (4), } \\
\text { Göz (3) }\end{array}$ & 17 & 42,5 \\
\hline $\begin{array}{l}\text { 3.Kıymetini } \\
\text { bilmeye yönelik }\end{array}$ & $\begin{array}{l}\text { Namus (26), Evlat sevgisi (20), Bayrak } \\
\begin{array}{ll}\text { (3), Paslanmaz çelik (3), İman (2), } \\
\text { Çocuk (1), Pırlanta (1) }\end{array}\end{array}$ & 56 & 26 & $\begin{array}{ll}\text { Evlat } & (7), \\
\text { Namus } & (6), \\
\text { Yuva (5) } & \end{array}$ & 18 & 45 \\
\hline $\begin{array}{l}\text { 4.Uçsuz, } \\
\text { bucaksız olmaya } \\
\text { yönelik }\end{array}$ & $\begin{array}{l}\text { Okyanus (9), Evren (2), Bilgi (1), Nirvana } \\
\text { (1) }\end{array}$ & 13 & 6 & - & - & - \\
\hline $\begin{array}{l}\text { 5.Kategori } \\
\text { girmeyen }\end{array}$ & Bal (3), Çınar ağacı (2), Dağ (2) & 7 & 3 & - & - & - \\
\hline & Toplam & 217 & 100 & Toplam & 40 & 100 \\
\hline
\end{tabular}

Tablo 9'a göre, 217 öğretmen adayı tarafından geliştirilen 34 metafor 4 kategori altında, 40 öğretmen tarafından geliştirilen 9 metafor ise 3 kategori altında toplanmıştır. Buna göre öğretmen adayları tarafından en fazla "Fedakarlığa yönelik" kategorisinde (f:72, \%33) metafor geliştirilirken, en az ise "Uçsuz, bucaksız olmaya yönelik" kategorisinde (f:13, \%6) metafor geliştirilmiştir. Öğretmenler tarafından en fazla "Kıymetini bilmeye yönelik" kategorisinde ( $f: 18, \%$ 45) metafor geliştirilirken, en az ise "Fedakarlığa yönelik" kategorisinde (f:5, \% 12,5) metafor geliştirilmiştir. Kategorilerin oluşmasında etkili olan öğretmen ve adaylarının tanımlamalarına ilişkin dikkat çekici bazı ifadeler aşağıda verilmiştir: 
"Vatanseverlik göz gibidir. Çünkü göz vücudumuzda hassas olan bir bölgedir ve kesinlikle iyi bir şekilde korunması gereken bir uzuvdur. Vatanseverlikte böyledir bizim için çok hassas olan ve kesinlikle büyük bir özveri ile korunması gereken bir değerdir. (ÖE19)"

"Vatanseverlik Atatürk gibidir. Çünkü, büyük fedakarlıkları sayesinde ülke kurtuluşa ermiștir. Vatanseverlikte fedakârlık gerektirir. (ÖE10)"

"Vatanseverlik kalp gibidir. Çünkü kalp insanın hayati organlarından biridir. Insanın damarlarına kanı pompalayan, insanın yaşamasını, hayatta kalmasını birçok organın kullanılmasını sağlayan bir organdır. Vatanseverlikte kalp gibi ülkeyi yaşatır. Ülkenin hayatta kalmasını sağlar. (ÖE4)"

"Vatanseverlik paslanmaz çelik gibidir. Çünkü vatanseverlik ne kadar darbe vurulursa vurulsun hammaddesi çelik gibidir değişmez aynı kalır. (ÖA1E5)"

"Vatanseverlik namus gibidir. Çünkü insanı insan yapan özellik namustur. Ölene kadar koruması gerekir ve namusu için gerekirse canını verir. Vatanseverlikte ölene kadar içimizde diri tutulması gerekir. (ÖA4K15)"

"Vatanseverlik aşk gibidir. Çünkü nasıl ki bir insana sevdalandığımızda ondan karşılık beklemez onu koşulsuz seversek vatanımızı aynı şekilde sevmeliyiz. (ÖA3K18)"

"Vatanseverlik Ömer Halis Demir gibidir. Çünkü 30 kurşunu yiyip şehit olmak her baba yiğidin harcı değildir. (ÖA2E2)"

\section{Tablo 10}

"Yardımseverlik" Değerine Yönelik Geliştirilen Metaforların Kategorilere Göre Dağılımları

\begin{tabular}{|c|c|c|c|c|c|c|}
\hline \multirow{2}{*}{ Kategoriler } & \multicolumn{3}{|c|}{ Sosyal Bilgiler Öğretmen Adayları } & \multicolumn{3}{|c|}{ Sosyal Bilgiler Öğretmenleri } \\
\hline & Metaforlar & $f$ & $\%$ & Metaforlar & $f$ & $\%$ \\
\hline $\begin{array}{c}\text { 1.Karşılıksız } \\
\text { olmaya yönelik }\end{array}$ & $\begin{array}{c}\text { Baba (20), Anne (13), Kalp (10), Kızılay } \\
\text { (6), Organlarımız (3), Güneş (2), Devlet } \\
\text { (1), Görünmezlik (1), Hızır (1), Türk } \\
\text { Milleti (1), Vakıf (1), Yunus Emre (1) }\end{array}$ & 60 & 28 & $\begin{array}{l}\text { Anne (4), } \\
\text { Kalp (4) }\end{array}$ & 8 & 20 \\
\hline $\begin{array}{c}\text { 2.Faydalı olmaya } \\
\text { yönelik }\end{array}$ & $\begin{array}{c}\text { Güneş (15), İlk yardım Çantası (11), } \\
\text { Mum (10), Ahtapot (5), Ay (5), Toprak } \\
\text { (2), Yağmur (2), Yıldız (1) }\end{array}$ & 51 & 24 & $\begin{array}{l}\text { Güneş (5), } \\
\text { Toprak (5), } \\
\text { Ahtapot (1), } \\
\text { Ağaç (2) }\end{array}$ & 13 & 32,5 \\
\hline $\begin{array}{l}\text { 3.Gittikçe artmaya } \\
\text { büyümeye }\end{array}$ & $\begin{array}{c}\text { Sarmaşık (13), Zincir halkası (7), Çığ } \\
\text { (6), Dalga (5), Okyanus (3), Çiçeği } \\
\text { sulamak (2), Ateş (1) }\end{array}$ & 37 & 17 & - & - & - \\
\hline $\begin{array}{l}\text { 4.Birlik, beraberlik } \\
\text { içinde olmaya } \\
\text { yönelik }\end{array}$ & $\begin{array}{c}\text { Çimento (10), Karınca (10), Arı (4), } \\
\text { Kardeşlik (4), Komşu (3), Futbol (2), } \\
\text { Değirmen (1) }\end{array}$ & 34 & 16 & $\begin{array}{l}\text { Çimento (7), } \\
\text { Lokomotif } \\
\text { (4), Karınca } \\
\text { (2) }\end{array}$ & 13 & 32,5 \\
\hline $\begin{array}{l}\text { 5.En temel ihtiyacı } \\
\text { karşılamaya } \\
\text { yönelik }\end{array}$ & $\begin{array}{l}\text { Ekmek (10), Su (8), Tohum (2), Uyku } \\
\text { (2), Nefes (1) }\end{array}$ & 23 & 11 & $\begin{array}{l}\text { Su (2), Nefes } \\
\text { (1) }\end{array}$ & 3 & 7,5 \\
\hline $\begin{array}{c}\text { 6.Paylaşıldıkça } \\
\text { çoğalmaya yönelik }\end{array}$ & Gülümseme (9), Mutluluk (3) & 12 & 6 & $\begin{array}{l}\text { Mutluluk (2) } \\
\text { Kitap (1) }\end{array}$ & 3 & 7,5 \\
\hline & Toplam & 217 & 100 & Toplam & 40 & 100 \\
\hline
\end{tabular}


Tablo 10'a göre, 217 öğretmen adayı tarafından geliştirilen 40 metafor 6 kategori altında, 40 öğretmen tarafından geliştirilen 13 metafor ise 5 kategori altında toplanmıştır. Buna göre öğretmen adayları tarafından en fazla "Karşılıksız olmaya yönelik" kategorisinde (f:60, \%28) metafor geliştirilirken, en az ise "Paylaşıldıkça çoğalmaya yönelik" kategorisinde $(f: 12, \%$ 6) metafor geliştirilmiştir. Öğretmenler tarafından en fazla "Faydalı olmaya yönelik ve Birlik, beraberlik içinde olmaya yönelik" kategorilerinde $(f: 13, \% 32,5)$ metafor geliştirilirken, en az ise "En temel ihtiyacı karşılamaya yönelik ve Paylaşıldıkça çoğalmaya yönelik" kategorilerinde ( $f: 3$, $\% 7,5)$ metafor geliştirilmiştir. Kategorilerin oluşmasında etkili olan öğretmen ve adaylarının tanımlamalarına ilişkin dikkat çekici bazı ifadeler aşağıda verilmiştir:

"Yardımseverlik lokomotif gibidir. Çünkü lokomotif tüm vagonları çekip götürür. Yardımseverlikte insanları birbirine bağlar. (ÖE2)"

"Yardımseverlik karınca gibidir. Çünkü karınca benim yardımımla ne olabilir ki diye düşünmez ve elinden geleni yapar. Yardımseverlikte de az çok denilmez imkânlar ölçüsünde herkese el uzatilır. (ÖE18)"

"Yardımseverlik güneş gibidir. Çünkü güneş çıktığı zaman hem bizi ısıtır hem de çevremizdekileri ısıtıp ışık saçar. Yardımseverlikte çevreye ışık saçmak demektir (ÖK7)"

"Yardımseverlik yağmur gibidir. Çünkü nasıl ki kurumuş topraklar yağmura nasıl hasretse ihtiyaç sahibi insanlarda yardım severlere o kadar hasrettir. (ÖA1E5)"

"Yardımseverlik mum gibidir. Çünkü yanan bir mum yanmayan bir muma değdirilirse onu da aydınlatmış olur. (ÖA2E6)"

"Yardımseverlik okyanus gibidir. Çünkü okyanus suyundan bir damla alınsa bile eksilmez insanlarda yardımsever olarak hiçbir şey kaybetmezler. (ÖA3K4)"

"Yardımseverlik çimento gibidir. Çünkü nasıl ki çimento tuğlaları birbirine sıkıca tutturursa yardımlarda toplumu birbirine kenetler. (ÖA1K16)"

\section{SONUÇ, TARTIŞMA VE ÖNERILER}

Öğretmen adayları anne şefkati, baş parmak, bayram, beyaz güvercin, cennet, doğa, güvercin, kağnı, kaktüs, merhem, orman, para, yeşil metaforlarını sadece barış değeri için; ampül, apartman, baraj, beyin cerrahı, bilgisayar, felsefe, hayaller, ışık, Japonya, köprü, laboratuar, matematik, merak, meyve ağacı, mikroskop, teknoloji, teleskop, Tübitak metaforlarını sadece bilimsellik değeri için; adalet, beyaz renk, bulut, bumerang, çanak anten, değerli maden, din, fedakarlık, fotoğraf makinesi, hakim, harita, hazine, hırka, Hz.Ömer, inci, karakter, karlı dağ, Kur'ân-ı Kerîm, Mevlana, nesli tükenen tür, ok, portakal, puzzle, saat, sıfır rakamı, süzme yoğurt, şeffaf kağıt, terazi, yay metaforlarını sadece dürüstlük değeri için; Amerika, atmosfer, balık, balon, bardak, barış, çikolata, çöl, ekmek-su, futbol maçı, hayal, İstiklal Marşı, kartal, kurt, Kurtuluş Savaşı, kuş, muhabbet kuşu, nar, on sekiz yaş, oyun, silah, şairin kalemi, uçurtma, vatan metaforlarını sadece özgürlük değeri için; akrep ile yelkovan, antika, ayçiçeği, beyin, binanın temeli, gece-gündüz, kanun, kardeş, kök, Martin Luther King, merdiven, namaz, örtü, şeker metaforlarını sadece saygı değeri için; atkı, boş resim defteri, çay,evlat, fidan, fiskyizm, gül, ırmak, kalkan, kartopu, maden, pasta, ruh, rüya, selvi ağacı, soba, telefon, ütopya, yol, yorgan metaforlarını sadece sevgi değeri için; ağırlık, alarm, anahtar, araba lastiği, bilinç, borç, direksiyon, ezan, gemi, hayat, kelepçe, Nelson Mandela, öğrenci, öğretmen, set, sınav, tren, yalan metaforlarını sadece sorumluluk değeri için; Atatürk, bal, bilgi, Çanakkale, evlatsevgisi, Hz.Ali, iman, kolon, maya, Mehmetçik, Muhsin Yazıcığlu, namus, Nene Hatun, nirvana, Ömer Halisdemir, paslanmaz çelik, Şerife Bacı metaforlarını sadece vatanseverlik değeri için; ahtapot, çiçeği sulamak, çimento, dalga, değirmen, futbol, görünmezlik, Hızır, ilk yardım çantası, karınca, Kızılay, komşu, Türk Milleti, uyku, vakıf, Yunus Emre, zincir halkası metaforlarını sadece yardımseverlik değeri için üretmişlerdir.Öğretmen adaylarının 9 değer için oluşturduğu toplam 233 metaforun 
172'si birbirinden farklı olup 61 tanesi ise ortak olarak üretilen metaforlardır.En fazla özgürlük değeri (24) için en az ise barış ve saygı değerleri (14) için farklı metaforlar üretilmiştir.

Öğretmenler beyaz güvercin, kardeş, misk, pasta, zeytin dalı metaforlarını sadece barış değeri için; deney, meşale, uzay metaforlarını sadece bilimsellik değeri için; ayna, cam, cetvel, hazine, Hz.Ömer, ok, saat ve tuz metaforlarını sadece dürüstlük değeri için; anahtar, arı, bebek, gökyüzü, gölge, kuş metaforlarını sadece özgürlük değeri için; aslan, bayram, hiyerarşi, iskelet, köprü, patlamış mısır, yeni gelin metaforlarını sadece saygı değeri için; akarsu, barış, bilgi, çiçek, çikolata, deniz, huzur, yağmur damlası, metaforlarını sadece sevgi değeri için; beyin, öğrenci metaforlarını sadece sorumluluk değeri için; Atatürk, evlat namus, Seyit Onbaşı, yuva metaforlarını sadece vatanseverlik değeri için; ağaç, ahtapot, çimento, karınca, kitap, lokomotif, mutluluk metaforlarını sadece yardımseverlik değeri için üretmişlerdir. Öğretmenlerin 9 değer için oluşturduğu toplam 68 metaforun 51' i birbirinden farklı olup 17 tanesi ise ortak olarak üretilen metaforlardır. En fazla dürüstlük ve sevgi değerleri (8) için en az ise sorumluluk değeri (2) için farklı metafor üretilmiştir.

Öğretmen adayları tarafından; Barış değerinde en çok ifade edilen çocuk metaforu (38) masumiyet sembolü olmaya yönelik kategorisinde olup sadece 3.sınıf düzeyindeki kadın öğretmen adayları tarafından ifade edilmemiş olup en çok 3.sınıf erkek öğretmen adayları (12) tarafından ifade edilmiştir. Bayram, beyaz güvercin ve gülümseme metaforları sadece kadın öğretmen adayları tarafından ifade edilmiştir. Keçe (2014) tarafından yapılan çalışmada da öğretmen adayları tarafından Barış değeri için oluşturulan Beyaz güvercin, güneş, çiçek ve su metaforları çalışma sonuçları ile benzerlik göstermektedir. Bilimsellik değerinde en çok ifade edilen uzay metaforu (25) uçsuz bucaksız olmaya yönelik kategorisinde olup sadece 1 . ve 2 . sınıf düzeyindeki kadın öğretmen adayları tarafından ifade edilmemiş olup en çok 3.sınıf kadın öğretmen adayları (8) tarafından ifade edilmiştir. Işık, ilaç ve kitap metaforları sadece kadın öğretmen adayları tarafından ifade edilmişken meşale metaforu sadece erkek öğretmen adayları tarafından ifade edilmiştir. Dürüstlük değerinde en çok ifade edilen ayna metaforu (29) her zaman doğruyu göstermeye yönelik kategorisinde her sınıf düzeyindeki öğretmen adayları tarafından ifade edilmiş olup en çok 2. ve 4.sınıf kadın öğretmen adayları (6) tarafından ifade edilmiştir. Beyaz renk metaforu sadece her sınıf düzeyindeki kadın öğretmen adayları tarafından ifade edilmiştir. Özgürlük değerinde en çok ifade edilen kuş metaforu (106) engellerin olmaması yönelik (101) ve temsiliyete yönelik (5) kategorilerinde olup her sınıf düzeyindeki öğrenciler tarafından ifade edilmiş ve en çok 1. ve 3.sınıf kadın öğretmen adayları (23) tarafından ifade edilmiştir. Saygı değerinde en çok ifade edilen baba metaforu (25) karşılıksız olmaya (22) ve menfaate-koşula yönelik (3) kategorilerinde olup sadece 1. ve 2. sınıf düzeyindeki erkek öğretmen adayları tarafından ifade edilmemiş olup en çok 3.sınıf kadın öğretmen adayları (8) tarafından ifade edilmiştir. Ayrıca baba metaforu her sınıf düzeyindeki kadın öğretmen adayları tarafından toplamda 19 defa ifade edilmişken sadece 3. ve 4. Sınıf erkek öğretmen adayları tarafından 6 defa tekrar edilmiştir Aile, gölge metaforları sadece kadın öğretmen adayları, aslan ve örtü metaforları sadece erkek öğretmen adayları maymuncuk metaforu ise tüm sınıf düzeyinde hem kadın hem de erkek öğretmen adayları tarafından ifade edilmiştir. Sevgi değerinde en çok ifade edilen anne metaforu (28) karşılıksız olmaya yönelik kategorisinde her sınıf düzeyindeki öğretmen adayları tarafından ifade edilmiş olup en çok 3.sınıf kadın öğretmen adayları (6) tarafından ifade edilmiştir. Ayrıca anne metaforu her sınıf düzeyindeki kadın öğretmen adayları erkek öğretmen adaylarına göre daha fazla sayıda ifade etmişlerdir. Sorumluluk değerinde en çok ifade edilen baba (25) ve anne (20) metaforları işini aksatmamaya yönelik kategorilerinde olup her ikisi de en çok 3.sınıf kadın öğretmen adayları tarafından ifade edilmiştir. Tüm sınıf düzeyinde Aşk metaforu sadece kadın öğretmen adayları, sınav, tren ve yalan metaforları sadece erkek öğretmen adayları tarafından ifade edilmiştir. Vatanseverlik değerinde en çok ifade edilen aşk metaforu (34) olmazsa olmaza yönelik kategorisinde her sınıf düzeyindeki öğretmen adayları tarafından ifade edilmiş olup en çok 1.sınıf kadın öğretmen adayları (7) tarafından ifade edilmiştir. Temel metaforu sadece her sınıf düzeyindeki kadın 
öğretmen adayları tarafından ifade edilmiştir. Yardımseverlik değerinde en çok ifade edilen baba metaforu (20) karşıııkız olmaya yönelik kategorisinde en çok 2.sınıf kadın öğretmen adayları (5) tarafından ifade edilmiştir.

Sonuç olarak; araştırmada elde edilen metaforlarla öğretmen adayları metaforları için 32, öğretmenlerin metaforları için ise 27 farklı kategori geliştirilmiştir. Öğretmenlerin ürettiği metaforlar, aydınlatmaya, temsiliyete yönelik, olmazsa olmaza, hareket alanını kısıtlamaya ve gittikçe artmaya büyümeye yönelik kategorilerinde yer bulmamıştır. Hem öğretmenler hem de öğretmen adayları en çok dürüstlük en az ise bilimsellik değeri ile ilgili metafor üretmişlerdir. Her iki grupta da en çok üretilen metafor özgürlük değeri için kuş metaforudur.

Öneri olarak; Evrensel değerlere kitaplarda yer verilme durumuna yönelik, ilköğretim öğrencilerin görüşlerine yönelik olarak farklı çalışmalar yapılabilir.

\section{KAYNAKLAR}

Akbaş, O. (2004). Türk Milli Eğitim Sisteminin Duyuşsal Amaçlarının Ilköğretim ikinci Kademedeki Gerçekleşme Derecesinin Değerlendirilmesi. Doktora Tezi, Gazi Üniversitesi, Eğitim Bilimleri Enstitüsü, Ankara.

Akhan, N., E., Kılıçoğlu, G. ve Gedik, H (2014). Sosyal Bilgiler Öğretmenliği Birinci Sınıf Öğrencilerinin Sosyal Bilgiler ve Sosyal Bilimlere Yönelik Metaforları, Turkish Studies-International Periodical For The Languages, Literature and History of Turkish or Turkic, 9(8), 73 - 90.

Avcl, E. (2009). Sosyal Bilgilerde Karakter Eğitimi, (Edt. M.Safran), Sosyal Bilgiler Öğretimi, 149-161. Ankara: Pegem A

Balcı, F. A. ve Yelken Yanpar, T. (2010). İlköğretim Öğretmenlerinin "Değer" Kavramına Yükledikleri Anlamlar. Hacettepe Üniversitesi Eğitim Fakültesi Dergisi, 39, 81-90.

Bolay, S. H. (2010). Değerlerimiz ve Günlük Hayat. Dem Dergi, 1 (1), 12-19.

Chapin, J., R. (2006). Elementary Social Studies: A Practical Guide Available at: http://books.google.com.tr/books?id=71UkAQAAMAAJ\&hl=tr\&source=gbs_navlinks_s

Çelikkaya, T. ve Yakar, H. (2015). Sosyal Bilgiler Öğretmen Adaylarının Sosyal Bilgiler Kavramına Illişkin Algıları: Metafor Analizi Örneği, International Online Journal of Educational Sciences, 7(4), 188-207.

Demircioğlu, İ. H. (2006). Sosyal Bilgiler Öğretmen Adaylarının Sosyal Bilimler Hakkındaki Görüşleri. Türk Dünyası Sosyal Bilimler Dergisi (Bilig), 36, 113-124.

Doğan, i. (2007). Vatandaşlık Demokrasi ve İnsan Hakları, (6.Baskı) Ankara: Pegem A

Ercan, İ. (2001), ilköğretim Sosyal Bilgiler Programında Ulusal ve Evrensel Değerler, Yüksek Lisans Tezi, Çanakkale On Sekiz Mart Üniversitesi, Sosyal Bilimleri Enstitüsü, Ankara.

Evirgen, Ö. F. (2016). Illköğretim Sosyal Bilgiler 7 Öğretmen Kılavuz Kitabı, Ankara: Ekoyay Yay.

Forceville, C. (2002). The Identification of Target and Source in Pictorial Metaphors. Journal of Pragmatics, 34 (1), 1-14.

Girmen, P. (2007). Ilköğretim Öğrencilerinin Konuşma ve Yazma Sürecinde Metaforlardan Yararlanma Durumları. Doktora Tezi, Anadolu Üniversitesi, Eğitim Bilimleri Enstitüsü, Eskişehir.

Goldstein, L. B. (2005). Becoming a Teacher as a Hero's Journey: Using metaphor in Preservice Teacher Education. Teacher Education Quarterly, 32 (1), 7-24.

Karabıyık, E. Ü. (2016). Ilköğretim Sosyal Bilgiler 6 Öğretmen Kılavuz Kitabı, Ankara: Evren Yay.

Kaya, M. F. (2013). Sosyal Bilgiler Öğretmen Adaylarının "Küresel Isınma", Kavramına Yönelik Metafor Algıları, Doğu Coğrafya Dergisi, 18 (29), 117-134.

Kaya, M. F. (2014). Sosyal Bilgiler Öğretmen Adaylarının Çevre Sorunlarına Illişkin Algıları: Metafor Analizi Örneği, Turkish Studies- International Periodical for The Languages, Literature and History of Turkish or Turkic, 9 (2), 917-931.

Keçe, M. (2014) Tarih ve Sosyal Bilgiler Öğretmen Adaylarının Bazı Tarih Kavramlarına Illişkin Algılarının Metaforlar Yoluyla Analizi, Hacettepe Üniversitesi Eğitim Fakültesi Dergisi (H. U. Journal of Education), 29(4), 143-156.

Koç, K. (2007). Ilköğretim 7. Sınıflarda Okutulan Vatandaşlık ve Insan Hakları Eğitimi Dersinde Öğrenciye Kazandırılması Amaçlanan Evrensel Değerlere ilişskin Tutumlar Üzerinde Öğretim Sürecinin Etkisi, Yüksek Lisans Tezi, Fırat Üniversitesi, Sosyal Bilimler Enstitüsü, Elazığ. 
Koçoğlu, E. (2014). Sosyal Bilgiler Öğretmenlerinin Sosyal Bilgiler Kavramına İlişkin İmgesel Algıları, Ahi Evran Üniversitesi Kurşehir Eğitim Fakültesi Dergisi, 15 (3), 107-126.

Leavy, A., M., Mcsorley, F., A. \& Bote, A., L. (2007). An Examination of What Metaphor Construction Reveals About the Evolution of Preservice Teachers' Beliefs About Teaching and Learning, Teaching and Teacher Education, 23: 1217-1233. doi:10.1016/j.tate.2006.07.016

Meral, E., Küçük, B. ve Figen Gedik, F. (2016). Sosyal Bilgiler Öğretmen Adaylarının Çevre Kavramına Illişkin Metaforik Algıları, Kastamonu Eğitim Dergisi, 24(1), 65-78.

Miles, M. B., \& Huberman, A. M. (1994). Qualitative Data Analysis (2nd ed.). Thousand Oaks, London: Sage Publications

Milli Eğitim Bakanlığı [MEB] (2017) Sosyal Bilgiler Dersi Öğretim Programı (illkokul ve Ortaokul 4, 5, 6 ve 7. Siniflar

Moser, K. S. (2000). Metaphor Analysis in Psychology - Method, Theory, and Fields of Application. Forum: Qualitative Social Research, 1 (2).

Mutluer, C. (2015) Sosyal Bilgiler Öğretmen Adaylarının "Hoşgörü" Kavramına İlişkin Metaforik Algıları. Tarih Okulu Dergisi (TOD) Yıl 8, Sayı XXII, ss. 575-595. DOI No: http://dx.doi.org/10.14225/Joh735

Özbaş, B., Ç. (2012). Sosyal Bilgiler Öğretmeni Olarak, Ben Kimim? Sosyal Bilgiler Öğretmenlerinin Mesleki Kimliklerine Yönelik Görüşlerinin Metafor Analizi Yoluyla İncelenmesi, Turkish Studies International Periodical For The Languages, Literature And History Of Turkish Or Turkic, 7 (2), 821838.

Özensoy, A.U. ve Aynacı, C. (2016). ilköğretim Sosyal Bilgiler 5 Öğretmen Kılavuz Kitabı, Ankara: Berkay Yay.

Özkalp, E. (2003). Kültür, (Edt. E, Özkalp), Davranış Bilimlerine Giriş. 3. Baskı, 57-74, Eskişehir: Anadolu Üniversitesi Yayını No:1355

Öztürk, C. ve Otluoğlu, R. (2011). Sosyal Bilgiler Öğretiminde Edebi Ürünler ve Yazılı Materyaller, (4. Baskı), Ankara: Pegem A.

Parashar, S., Dhar S. ve Dhar, U. (2004). Perception of Values: A Study of Future Professionals. Journal of Human Values, $10 \quad$ (2), 143-152. Retrieved from http://jhv.sagepub.com/content/10/2/143.full.pdf+html

Patton, M., Q. (2014). Nitel Araştırma ve Değerlendirme Yöntemleri (Çeviri Editörleri: M. Bütün-S. B. Demir) Ankara :Pegem A

Sanchez, A., Barreiro, J., M. \& Maojo, V. (2000). Desing of Virtual Reality Systems for Education: A Cognitive Approach, Education and Information Technologies, 5(4),345-362

Schmitt, R. (2005). Systematic metaphor analysis as a method of qualitative research. The Qualitative Report, 10 (2), 358-394.

Schwartz, S.H. (1964), Universals in the Content and Structure of Values: Theoretical Advances and Empirical Tests in 20 Countries, (Edt. M.P. Zanna), Advances in Experimental Social Psychology, 25, 1-65 San Diego: Academic Press.

Şahin, S. C., Bayram, Ö. ve Midilli, A. (2016). Ilköğretim Sosyal Bilgiler 4 Öğretmen Kılavuz Kitabı, Ankara: Koza yay.

Tuna, Y. E. ve Budak, F. M. (2013). Sosyal Bilgiler Öğretmen Adaylarının "Tarih" Kavramına İlişkin Algılarının Mecazlar / Metaforlar Yardımıyla Analizi. Adıyaman Üniversitesi Sosyal Bilimler Enstitüsü Dergisi, (Sosyal Bilgiler Öğretimi Özel Sayısı), 6 (14), 609-642.

Vadeboncoeur, J. A \& Torres, M., N. (2003). Constructing and Reconstructing Teaching Roles: A Focus On Generative Metaphors and Dichotomies, Discourse: Studies in the Cultural Politics of Education, Carfax Publishing, 24(1).87-103 DOI: 10.1080/01596300303034

Yıldırım, A. ve Şimşek, H. (2013). Sosyal Bilimlerde Nitel Araştırma Yöntemleri. (9.Genişletilmiş Baskı) Ankara: Seçkin 


\section{Metaphor Perceptions of Social Studies Teachers and Preservice Teachers Related to Universal Values}

\author{
Assoc.Prof.Dr. Tekin Çelikkaya \\ Ahi Evran University-Turkey \\ tcelikkaya@gmail.com
}

\author{
Osman Seyhan (M.A.Stud.) \\ Ahi Evran University-Turkey \\ osmanseyhan40@gmail.com
}

\begin{abstract}
This study aims to identify the metaphors for the use of social studies teachers and preservice social studies teachers in explaining perceptions of universal values. This study is a qualitative research in the descriptive scanning model. In the process of collecting and interpreting data, phenomenology that one of qualitative research methods was used. The study group constituted 106 preservice social studies teachers, including 46 (43.4\%) female and 60 (56.6\%) male at the Ahi Evran University in the 2016-2017 school year and 40 Social Studies Teachers working in the city center of Kursehir. The data were gathered through the "Social Studies Teachers and Preservice Social Studies Teachers Metaphors Questionnaire for Universal Values" questionnaire developed by the researchers. With the metafores obtained in the research, 32 different categories for preservice' metaphors teachers and 27 different categories for teachers' metaphors were developed. Metaphores produced by teachers did not find their categories for enlightenment, representation, necessity, restricting the field of movement and growing gradually. The total of 233 metaphors created by the preservice teacher for 9 values are 172 different from each other, and 61 are metaphor produced jointly. Different metaphors have been produced for at least peace and respect values (14) for the highest freedom value (24). 51 of the 68 metaphors created by teachers are different from each other and 17 are metaphor that is produced jointly. Different metaphors have been produced for the most honesty and love values (8) and at least for the responsibility value (2). Metaphor was produced most for honesty in both groups.
\end{abstract}

Keywords: Universal values, metaphor, social studies teacher, Preservice social studies teacher

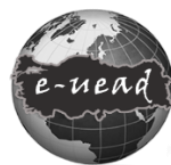

E-International Journal of Educational Research, Vol: 8, No: 3, 2017, pp.65-87

DOI: 10.19160/ijer.342330

Received: 08.10.2017 Accepted: 20.11 .2017

\section{Suggested Citation:}

Çelikkaya, T. \&. Seyhan, O. (2017). Metaphor Perceptions of Social Studies Teachers and Preservice Teachers Related to Universal Values. E-International Journal of Educational Research, Volume: 8, Number: 3, 2017, ss. 65-87, DOI: 10.19160/ijer.342330 


\section{EXTENDED ABSTRACT}

Purpose: There are many classifications about values. Spranger (1928) examined the values in six groups as aesthetic, theoretical (scientific), economic, political, social and religious values. Rokeach (1973) investigated in two groups as goal and instrumental values. Schwartz (1964: 5-11) examined ten values in the group of self-interest, self-esteem, consensus, hedonism, success, power, security, conformity, tradition, benevolence and universalism. Thomas Lickona values have been examined as tolerance, prudence, self-discipline, benevolence, compassion, cooperation, courage, honesty, fairness and democratic values, in particular respect and responsibility. Edward Wynne and Kevin Ryan evaluated values as justice, prudence, moderation, courage, faith, hope, charity, respect. William Bennet has determined values, compassion, self-discipline, responsibility, work, friendship, courage, determination, honesty, loyalty, and faith. (Leming, 1996; Akt: Avcl, 2009:156). Ercan (2001) divided the values into two as national and universal values. National Values: National, state, homeland, army, republic, heroism, language, traditions and national anthems are national symbols created by national flags and national holidays. Democracy, human rights and freedoms, independence, civilization, peace, tolerance, respect, love, understanding, reconciliation, science, equality and environmental sensitivity are universal values. When the values to be directly taught in Social Studies curriculum in Turkey are examined, it is observed that in other researches about values, "responsibility, equality, justice, freedom, tolerance, respect, motivation, trust, commitment, autonomy, ambition, Tolerance, helpfulness, honesty, love, obedience, success".

Within the scope of the research, the values of Peace, Scientificity, Honesty, Freedom, Respect, Love, Responsibility, Patriotism and Charity are determined. These values are included in the grouping of universal and national values when we look at social, individual and family values or other classifications or Balcı and Yelken Yanpar, 2010; Doğan, 2007; Ercan, 2001; Schwartz, 1964; Spranger, 1928; Rokeach, 1973; Thomas Lickona (Dirct by: Hunter, 2009) is in the grouping of values.Primary Life Science (1-3 th grades),"Turkish ( $1-8^{\text {th }}$ grades), Social Studies (4-7 ${ }^{\text {th }}$ grades) And Religion Culture and Moral Knowledge ( $4-8^{\text {th }}$ grades) as common values that are aimed to be gained to the students in the curriculum.

Social Studies is a value education course. One of the striking points in program changes in 2005 and 2017,value education is emphasized in programs. When the Social Studies Curriculum of 2005 is examined, it is aimed to give a total of 20 values to the students. These values are defined as; "Peace, Independence, Scientificness, Diligence, Sensibility, Honesty, Aesthetics, Tolerance, Hospitality, Freedom, Respect, Being Healthy, Love, Responsibility, Cleanliness, Patriotism, Helpfulness" (Evirgen,2016; Karabıyık,2016; Özensoy and Aynacl,2016; Şahin, Bayram and Midilli,2016). When the Social Studies Curriculum of 2017 is examined, it is aimed that some of these values will be removed and the value of 18 new associations will be added (MEB,2017). Peace, Scientificity, Honesty, Freedom, Respect, Love, Responsibility, Patriotism and Charity values are examined in the scope of the research. These values are both social, individual and family values.

This study aims to identify the metaphors for the use of social studies teachers and preservice social studies teachers in explaining perceptions of universal values. For this purpose, answers to the following questions regarding universal values were sought;

1. What are the metaphors for Social Studies teachers and preservice teachers regarding universal values?

2. What conceptual categories of emerging metaphors about these universal values can be grouped in terms of their common characteristics? 
Method: This study is a qualitative research in the descriptive scanning model. In the process of collecting and interpreting data, phenomenology that one of qualitative research methods was used. The study group constituted 106 preservice social studies teachers, including 46 (43.4\%) females and 60 (56.6\%) male at the Ahi Evran University in the 2016-2017 school year and 40 Social Studies Teachers working in the city center of Kursehir. The data were gathered through the "Social Studies Teachers and Preservice Social Studies Teachers Metaphors Questionnaire for Universal Values" questionnaire developed by the researchers.

Results, Discussion, Conclusion: With the metafores obtained in the research, 32 different categories for preservice' metaphors teachers and 27 different categories for teachers' metaphors were developed. Metaphores produced by teachers did not find their categories for enlightenment, representation, necessity, restricting the field of movement and growing gradually. The total of 233 metaphors created by the preservice teacher for 9 values are 172 different from each other, and 61 are metaphor produced jointly. Different metaphors have been produced for at least peace and respect values (14) for the highest freedom value (24). 51 of the 68 metaphors created by teachers are different from each other and 17 are metaphor that is produced jointly. Different metaphors have been produced for the most honesty and love values (8) and at least for the responsibility value (2). 